\title{
Working
}

Paper

INTERNATIONAL MONETARY FUND 


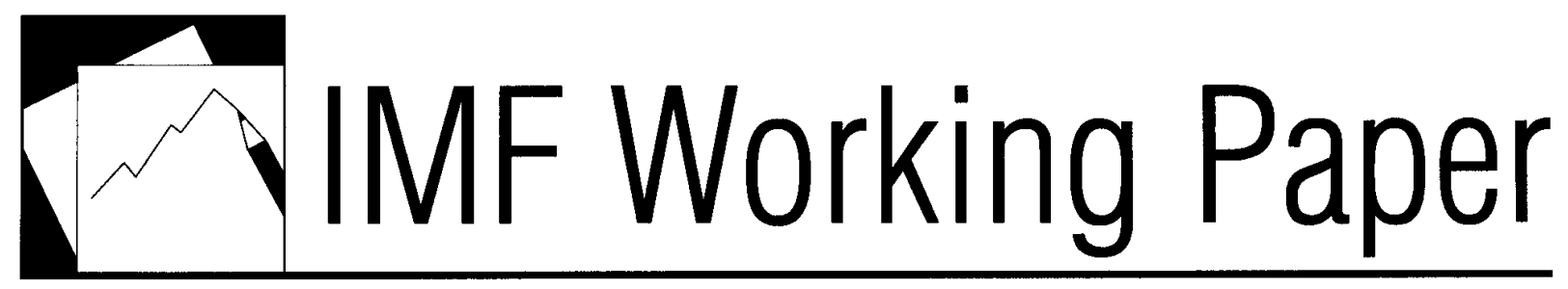

Deciding to Enter a Monetary Union: The Role of Trade and Financial Linkages

Ruy Lama and Pau Rabanal 


\title{
IMF Working Paper
}

Institute for Capacity Development

\section{Deciding to Enter a Monetary Union: The Role of Trade and Financial Linkages}

\author{
Prepared by Ruy Lama and Pau Rabanal ${ }^{1}$
}

Authorized for distribution by Jorge Roldós

October 2012

\section{This Working Paper should not be reported as representing the views of the IMF.}

The views expressed in this Working Paper are those of the author(s) and do not necessarily represent those of the IMF or IMF policy. Working Papers describe research in progress by the author(s) and are published to elicit comments and to further debate.

\begin{abstract}
This paper evaluates the role of trade and financial linkages in the decision to enter a monetary union. We estimate a two-country DSGE model for the U.K. economy and the euro area, and use the model to compute the welfare trade-offs from joining the euro. We evaluate two alternative scenarios. In the first one, we consider a reduction of trade costs that occurs after the adoption of a common currency. In the second, we introduce interest rate spread shocks of the same magnitude as the ones observed during the recent debt crisis in Europe. The reduction of trade costs generates a net welfare gain of 0.9 percent of life-time consumption, while the increased interest rate spread volatility generates a net welfare cost of 2.9 percentage points. The welfare calculation suggests two ways to preserve the welfare gains in a monetary union: ensuring fiscal and financial stability that reduces macroeconomic country risk, and increasing wage flexibility such that the economy adjusts to external shocks faster.
\end{abstract}

JEL Classification Numbers: E52; F41; F42; F44.

Keywords: Trade Costs; DSGE Model; Monetary Union.

Author’s E-Mail Address rlama@imf.org; prabanal@imf.org

\footnotetext{
${ }^{1} \mathrm{Mr}$. Lama is an Economist in the European Department and Mr. Rabanal is an Economist in the Western Hemisphere Division of the IMF Institute. We thank Jorge Roldós, Gaston Gelos, Mick Devereux and seminar participants at the IMF Institute, the Federal Reserve Board, and the 2011 Society of Computational Economics Conference for their useful comments. All errors are our own.
} 


\section{Contents}

1. Introduction

2. The Model

2.1 Households, International Assets Markets, and Staggered Wage Setting .............. $\underline{8}$

2.2 Firms

2.3 Closing the Model

3. Bayesian Estimation.



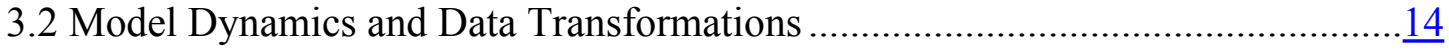

3.3 Estimation: Priors and Posteriors

4. Policy Analysis: Welfare Gains of Entering a Monetary Union

5. Sensitivity Analysis

6. Conclusions

Technical Appendix

References

Tables

Table 1

Table 2

Table 3

Table 4

Table 5

Table 6

Table 7

Figures

Figure 1

Figure 2

Figure 3

Figure 4

Figure 5
Calibrated Parameters $\frac{16}{17}$

Prior Distributions. 17

Posterior Distributions, structural parameters ........................................... $\frac{19}{19}$

Posterior Distributions, shocks parameters

Second Moments

Steady State Effects and Welfare Gains

Business Cycle Effects and Welfare Gains

Monetary Policy Rates in United Kingdom and the Euro Area: 1999-2011..... 47 Trade with Euro Area in France, Germany, Italy, Spain and the United

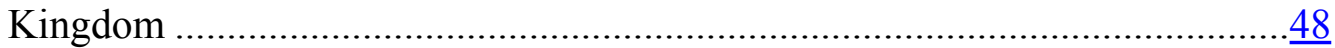
Risk Premium in France, Italy, Spain the United Kingdom............................49 Impulse Response Functions to 25 basis points increase in UIP Shock............ $\underline{50}$ Sensitivity Analysis of Welfare 


\section{Introduction}

The economic crisis that started in 2007 has revived the debate on the benefits and costs of belonging to the European Monetary Union (EMU). The recent crisis has been particularly long lasting in some southern European countries, leaving a large public and private debt overhang. This situation is making it difficult to provide additional fiscal stimulus and is forcing deleveraging in the banking sector. In addition, exchange rate policy cannot be used as a tool to correct competitiveness problems and increase growth through net exports. As a result, some economists and market commentators have suggested that the costs of belonging to the EMU, also known as the euro area, might outweigh its benefits for some of its members. ${ }^{1}$ The costs of belonging to the EMU are mostly related to the loss of monetary and exchange rate policy as an instrument for macroeconomic stabilization. These costs are amplified by the EMU's design flaws, most notably the lack of fiscal and labor market integration that are needed in an optimal currency area (Mundell, 1961). However, all the costs of a monetary union have to be assessed relative to the benefits brought about by lower transaction costs associated to having a common currency, and the disappearance of nominal exchange rate risk.

While this debate is taking place, the EMU has actually expanded since the beginning of the crisis: Malta and Cyprus joined in 2008, Slovakia in 2009, and Estonia in 2011. In fact, all country members of the European Union (EU) are expected to participate in the EMU once the convergence criteria are fulfilled. Yet, some countries have made it clear that they are not interested in joining the EMU. The United Kingdom (U.K.) and Denmark were granted opt-out clauses in 1997 and 1993 respectively. Both countries consider that the decision of entering the EMU should be approved by a referendum. Sweden never fulfilled the conditions to adopt the euro, by not entering the European Exchange Rate Mechanism (ERM II), which requires keeping the country's exchange rate in a narrow band with the euro for two years.

In the case of the U.K., the government of prime minister Tony Blair set in 1997 five economic tests to evaluate whether or not the country will benefit from adopting the euro. ${ }^{2}$ The five economic tests are :

1. Are business cycles and economic structures compatible so that we

\footnotetext{
${ }^{1}$ See Feldstein (2010) and Roubini (2011).

${ }^{2}$ See HM Treasury (1997).
} 
and others could live comfortably with the euro interest rates on a permanent basis?

2. If problems emerge is there sufficient flexibility to deal with them?

3. Would joining EMU create better conditions for firms making long-term decisions to invest in Britain?

4. What impact would entry into EMU have on the competitive position of the U.K.'s financial services industry, particularly the City's wholesale markets?

5. In summary, will joining EMU promote higher growth, stability and a lasting increase in jobs?

The British government conducted two evaluations: one in 1997 and the other in 2003. The 1997 report determined that the U.K. did not satisfy the five economic tests. The 2003 report mentioned that even though EMU membership could increase U.K. GDP between 5 and 9 percent, there was not a clear and unambiguous case for adopting the euro. ${ }^{3}$ The British current administration has pledged not to join the EMU over the course of the Parliament. ${ }^{4}$

Figure 1 illustrates the potential constraints that the U.K. economy would have faced if it had joined the EMU. Figure 1 plots the times series of the reference monetary policy rates set by the Bank of England (BoE) and the European Central Bank (ECB). In the recent period of financial turbulence (since 2007), the difference between the short-term interest has been less than one percentage point due to the synchronized effects of the Great Recession. The two reference rates have differed by more than 100 basis points quite often. For instance, between 2001 and 2005 the interest rate differential increased from 100 to 300 basis points. These differences are quite large and can have important macroeconomic effects on output and inflation. ${ }^{5}$

\footnotetext{
${ }^{3}$ See HM Treasury (2003).

${ }^{4}$ On October 5, 2011, Prime Minister David Cameron stated in a speech at the annual conservative party conference the following: "So let me say this: as long as I'm prime minister, this country will never join the euro". Speech available at http://www.telegraph.co.uk/news/politics/david-cameron/8809209/David-Cameronsspeech-to-Conservative-Party-Conference.html.

${ }^{5}$ For empirical evidence on the transmission mechanism of monetary shocks in the U.K. see DiCecio and Nelson (2007).
} 
If the British economy had followed the nominal interest rate to the level set by the ECB, it would have been more difficult to stabilize inflation and output over that period. ${ }^{6}$ Moreover, Figure 1 does not show the effects that unconventional monetary policies have had in long-term rates in the U.K. (we will comment on the effects of that policy below, in Figure 3).

Besides the costs in terms of relinquishing monetary policy and increased macroeconomic volatility, in this paper we consider two elements that are crucial in the decision of joining a currency area. The first element is the trade expansion that typically occurs after joining in a monetary union, due to lower transaction costs and disappearance of nominal exchange rate uncertainty. ${ }^{7}$ Figure 2 shows the expansion of trade in the euro area, measured as trade with the euro area (imports and exports) as percent of GDP. From 1990 until 2002, the share of intraregional trade of the largest economies of the euro area (Germany, France, Italy and Spain) increased from 16 to 23 percent of GDP. On the other hand, the U.K., who belongs to the EU but not to the EMU has experienced a more modest increase in trade with its EMU partners. We consider this expansion of trade as part of the benefits of joining a monetary union. ${ }^{8}$

The second key element of our analysis is the role of financial factors, as reflected in country risk premia. Figure 3 plots the 10-year government bond interest differential vis-a-vis the 10-year German bund. In the years before EMU accession, there was significant reduction of spreads for France, Italy, and Spain. Once the euro was created, this premium disappeared for EMU members because all government bonds where perceived to be the same by market participants. For France, Italy and Spain, this premium was lower than the one observed for the U.K. So if one where to study the EMU experience between 1999 and 2007, one would reach the conclusion that the risk premia had disappeared, and this had a positive welfare impact

\footnotetext{
${ }^{6}$ Entering the EMU may increase the synchronization of business cycles between the new member and the monetary union, reducing the costs of losing the ability to conduct monetary policy (Rose, 2008). However, the existing inflation differentials across EMU members indicate there is no full synchronization of business cycles. Rabanal (2009) provides with a DSGE model based evaluation of inflation differentials in the EMU.

${ }^{7}$ See Anderson and Wincoop (2004) and Rose (2008).

${ }^{8}$ For these countries, we also calculated the ratio of the sum of imports and exports with the euro area, relative to the sum of total imports and exports, obtaining the same qualitative results in terms of trade expansion. Santos Silva and Tenreyro (2010) provide a literature review on all the costs and benefits discussed in the literature of optimal currency areas.
} 
in countries that are net debtors. Since the summer of 2007, this trend reversed and country risk premia became positive again. In the case of Italy and Spain, the differential has fluctuated between 200 and 600 basis points during 2010 and 2012, while the same spread has edged down for the U.K. Bean (2011) quantifies the effects of unconventional monetary policy in the U.K. to have helped bring long term rates down by about 100 basis points. ${ }^{9}$ In this paper, we also evaluate how changes both in the level and volatility of the risk premium observed in the recent crisis impact the decision of adopting the euro.

The objective of this paper is to contribute to the debate on the desirability to join the EMU, with a novel focus on interest rate spread shocks. Our approach is to conduct this evaluation in an estimated dynamic stochastic general equilibrium (DSGE) model. The advantage of a fully-fledged DSGE model is that it can measure the impact of a change of policies (in this case, to join the euro area) on households' and firms' decisions, and hence it should be Lucas-critique free. The starting point of the analysis is a twocountry version of the Smets and Wouters (2007) general equilibrium model with nominal and real rigidities, which includes trade and financial linkages across countries. In particular, we follow Rabanal and Tuesta (2010) and incorporate incomplete financial markets and local currency pricing for exports. Parameter estimation is conducted with Bayesian methods and using data for the euro area and the U.K.

Using the estimated DSGE model, we compare the gains from having lower transaction costs in a monetary union, with the costs of increased macroeconomic volatility due to the loss of monetary and exchange rate policy. Then, we consider two different hypotheses regarding the behavior of interest rate spreads after EMU membership. ${ }^{10}$ Our results show that in tranquil times, lower trade costs in a monetary union generate a net welfare gain of 0.9 percentage points of life-time consumption. Even though a country loses its monetary and exchange rate policy, the expansion of trade more than compensates for the welfare costs of higher macroeconomic volatility. On the other hand, in a scenario of financial turbulence similar to what some southern European countries have faced during the crisis, the net welfare costs are 2.9 percent of life-time consumption. Even though in tranquil times

\footnotetext{
${ }^{9}$ See http://www.bankofengland.co.uk/publications/Documents/speeches/2011/speech478.pdf

${ }^{10}$ This exercise complements in a more formal way, the 5 economic tests proposed by former British prime minister Tony Blair in 1997.
} 
the welfare calculation of entering a monetary union might give a positive result, that can be easily be reverted in times of financial turbulence. This results gives a rationale to emphasize policies of financial stability and fiscal prudence in a monetary union. These help to reduce macroeconomic country risk and should help stabilize the risk premium over the business cycle.

The analysis in this paper abstracts from some issues that are relevant in the current crisis such as the role of collateral constraints at the household or corporate levels. In addition, we do not consider the restrictions imposed by shifting market sentiment on the ability to conduct countercyclical fiscal policy, which is needed during a severe recession in a currency union. The high levels of public and private debt would make the U.K. vulnerable to changes in capital flows or financing conditions during a situation of financial stress. Although we do not model these elements in this paper, we think that they would only increase the costs of belonging to a monetary union during times of financial turbulence. Hence, our main result of high net welfare costs under financial shocks would be preserved if we included these additional features. ${ }^{11}$

The paper is organized as follows. Section 2 describes the model. Section 3 discusses the Bayesian estimation and the business cycle properties of the model. Section 4 presents the welfare analysis. A sensitivity analysis is conducted in Section 5. Section 6 concludes.

\section{The Model}

This section presents the stochastic two country model that will be used to analyze linkages between the euro area and the U.K. The model is a twocountry version of a DSGE model similar to those by Christiano, Eichenbaum and Evans (2005) and Smets and Wouters (2003, 2007), where we include trade and financial linkages across countries. ${ }^{12}$ We discuss the main functional forms and describe the most important frictions of the economy, while in the appendix, we provide a detailed derivation of the model. We assume that there are two countries, home and foreign, of sizes $n$ and $1-n$, respectively. Each country produces a continuum of intermediate goods, indexed by

\footnotetext{
${ }^{11}$ For a model of a monetary union with a financial accelerator friction and fiscal policy constraints see Erceg and Lindé (2010).

${ }^{12}$ Rabanal and Tuesta (2010) have estimated a similar model for the United States and the euro area.
} 
$h \in[0, n]$ in the home country and $f \in[n, 1]$ in the foreign country, which are traded internationally. These intermediate goods are used in the production of the final good that is used for domestic final consumption, investment, and government spending, and hence it is not traded across borders. The model also incorporates linear shipping costs of moving goods internationally. As it is typically done in the literature, we follow Samuelson (1954) and introduce "iceberg" shipping costs. ${ }^{13}$ As we discuss throughout the paper, the main benefit of joining the currency area is that a fraction of these costs would disappear, leading to more trade creation. ${ }^{14}$

The model also includes several nominal and real frictions that are important to explain the data. We include habit formation in consumption, adjustment costs to investment, staggered price setting with indexation, and staggered wage setting. Our benchmark model assumes that there is local currency pricing for goods that are shipped internationally. In addition, we assume that there is an incomplete asset market structure at the international level: agents only have access to one non-contingent bond that is denominated in foreign-country currency. The model incorporates 14 shocks because in the econometric section we are interested in explaining 13 variables. Unless specified in the text, all shocks follow zero-mean $\mathrm{AR}(1)$ processes in logs.

\subsection{Households, International Assets Markets, and Stag- gered Wage Setting}

In each country, households obtain utility from consuming final goods $\left(C_{t}^{j}\right)$ with external habit formation, and dislike supplying labor $\left(N_{t}^{j}\right)$. They are subject to intertemporal $\left(D_{c, t}\right)$ and intratemporal $\left(D_{n, t}\right)$ preference shocks:

$$
E_{0} \sum_{t=0}^{\infty} \beta^{t} D_{c, t}\left[\log \left(C_{t}^{j}-b C_{t-1}\right)-D_{n, t} \frac{\left(N_{t}^{j}\right)^{1+\eta}}{1+\eta}\right],
$$

where $\beta \in[0,1]$ is the discount factor, $b \in[0,1]$ is the habit parameter, and $\eta>0$ is the inverse elasticity of labor supply with respect to the real wage. Markets are complete within each country and incomplete at the

\footnotetext{
${ }^{13}$ For applications of international macroeconomics models with shipping costs see Obstfeld and Rogoff (2000), Ravn and Mazzenga (2004), and Kose and Yi (2006).

${ }^{14}$ The reduction in "iceberg" costs captures not only the lower transaction costs associated with engaging in international trade with only one currency, but also the benefits of a decrease in nominal exchange rate volatility.
} 
international level. The budget constraint of home-country households is given by:

$$
P_{t}\left(C_{t}^{j}+I_{t}^{j}\right)+\frac{B_{t}^{j}}{R_{t}}+\frac{S_{t} D_{t}^{j}}{R_{t}^{*} \Psi\left(\frac{S_{t} D_{t}}{Y_{t} P_{t}}\right) U_{t}}+T_{t}=B_{t-1}^{j}+S_{t} D_{t-1}^{j}+W_{t}^{j} N_{t}^{j}+P_{t} R_{t}^{K} K_{t-1}^{j}+\Pi_{t}^{j}+\xi_{t}^{j},
$$

where $B_{t}^{j}$ and $D_{t}^{j}$ denote holdings of the domestic and foreign currency denominated bonds, $R_{t}$ is the home country gross nominal interest rate and $R_{t}^{*}$ is the foreign country gross nominal interest rate. $S_{t}$ is the nominal exchange rate expressed in units of domestic currency needed to buy one unit of foreign currency and $P_{t}$ is the price level of the final good. $T_{t}$ are lump-sum taxes that are used to finance government spending. $\xi_{t}^{j}$ denotes the payoff from engaging in trade of domestic state-contingent securities. ${ }^{15}$

Home-country households also face a cost of undertaking positions in the foreign bonds market. The $\Psi$ (.) function captures this cost and depends on the aggregate real holdings of the foreign assets in the entire economy, and therefore is taken as given by individual households. ${ }^{16}$ We also include an exogenous shock $\left(U_{t}\right)$ to the function $\Psi($.$) , which helps explains deviations$ from the uncovered interest rate parity condition. For this reason, we call this shock the "uncovered interest rate parity" (UIP) shock. ${ }^{17}$ The risk sharing condition, which forms the basis of the real exchange rate determination under incomplete markets, reads:

$$
E_{t}\left(\frac{C_{t}^{*}-b^{*} C_{t-1}^{*}}{C_{t+1}^{*}-b C_{t}^{*}} \frac{D_{c, t+1}^{*}}{D_{c, t}^{*}} \frac{P_{t}^{*}}{P_{t+1}^{*}}\right)=E_{t}\left(\frac{C_{t}-b C_{t-1}}{C_{t+1}-b C_{t}} \frac{D_{c, t+1}}{D_{c, t}} \frac{S_{t+1} P_{t}}{S_{t} P_{t+1}}\right) \Psi\left(\frac{S_{t} D_{t}}{Y_{t} P_{t}}\right) U_{t}
$$

where starred variables denote foreign-country counterparts to domestic variables. As is standard in international macroeconomic models, the risk sharing condition under incomplete markets equates the expected payoffs of investing

\footnotetext{
${ }^{15}$ In order to keep notation simple, we do not make the structure of the complete domestic asset markets explicit.

${ }^{16}$ This cost induces stationarity in the net foreign asset position. See Schmitt-Grohé and Uribe (2003) for applications in small open economy models, and Benigno (2009) in two-country models.

${ }^{17}$ Since the model does not include risk, we choose to not label this shock as a "risk premium" shock. However, in the welfare evaulation exercises, we calibrate this process using interest rate spreads across countries, which reflect risk premia.
} 
in each currency, using the expected growth in the marginal rate of substitution, and taking into account the cost $\Psi$ (.). We define the real exchange rate as the ratio of final goods prices, expressed in common currency:

$$
R E R_{t}=\frac{S_{t} P_{t}^{*}}{P_{t}} .
$$

Households rent capital to the firms that produce intermediate goods. $K_{t-1}^{j}$ and $I_{t}^{j}$ denotes holdings of capital stock and investment purchases, respectively. The real rental rate of capital is denoted by $R_{t}^{K}$. The capital accumulation dynamics are given by the following expression

$$
K_{t}^{j}=(1-\delta) K_{t-1}^{j}+V_{t}\left[1-S\left(\frac{I_{t}^{j}}{I_{t-1}^{j}}\right)\right] I_{t}^{j},
$$

where $\delta$ denotes the rate of depreciation and the adjustment cost function, $S($.$\left.) , is an increasing and convex function (i.e. S^{\prime}(), S^{\prime \prime}()>0\right)$. Furthermore, in the steady state $\bar{S}=\bar{S}^{\prime}=0$ and $\bar{S}^{\prime \prime}>0$. The $S$ (.) function summarizes the technology that transforms current and past investment into installed capital for use in the following period. This expression also includes an investmentspecific technology shock $\left(V_{t}\right)$.

Households obtain labor income from supplying labor to intermediate goods producers, for which they receive a nominal wage, $W_{t}^{j}$, and receive profits from intermediate and wholesale final goods producers $\Pi_{t}^{j}$. As in Erceg, Henderson, and Levin (2000; henceforth EHL), we assume that each household is a monopoly supplier of differentiated labor service, $N_{t}^{j}$. The household sells this service to a competitive firm that transforms it into an aggregate labor input. The labor input is used by the intermediate goods producers. The elasticity of substitution across types of labor is $\varepsilon_{w}$. Households set wages in a staggered way with a Calvo-type restriction. In each period, a fraction $1-\theta_{w}$ of households can reoptimize their posted nominal wage. The assumption of complete markets within each country allows to separate the consumption/saving decisions from the labor supply decision (see EHL).

\section{$2.2 \quad$ Firms}

The model has final goods, differentiated intermediate goods and composite intermediate goods producers. Final goods producers purchase a composite 
of intermediate home goods, $Y_{H, t}$, and a composite of intermediate foreignproduced goods, $Y_{F, t}$, to produce a homogeneous final good product. Intermediate differentiated domestic and foreign goods producers operate under sticky prices and monopolistic competition, and sell their products to intermediate domestic and foreign composite goods producers, who in turn sell these to final goods producers. Composite intermediate goods are traded across countries, while final goods are not.

\subsubsection{Final good producers and "iceberg" costs}

A continuum of final goods producers firms purchase a composite of intermediate home goods, $Y_{H, t}$, and a composite of intermediate foreign-produced goods, $Y_{F, t}$, to produce a homogeneous final good product. A fraction $\tau$ of imported intermediate inputs are lost in transit between the two countries. This functional form for transportation costs was first proposed by Samuelson (1954), and is also known in the literature as "iceberg costs". Therefore, the production of the final good is given by:

$$
Y_{t}=\left\{\omega^{\frac{1}{\theta}} Y_{H, t}^{\frac{\theta-1}{\theta}}+(1-\omega)^{\frac{1}{\theta}}\left[(1-\tau) Y_{F, t}\right]^{\frac{\theta-1}{\theta}}\right\}^{\frac{\theta}{\theta-1}},
$$

where $\omega$ denotes the fraction of home-produced goods that are used for the production of the final good, and $\theta$ denotes the elasticity of substitution between domestically produced and imported intermediate goods in both countries. The prices of these composite goods for the final good producers are given by $P_{H, t}$ and $P_{F, t}$. We can rewrite the weights as follows in the production function of the final good:

$$
Y_{t}=\left[\omega^{\frac{1}{\theta}} Y_{H, t}^{\frac{\theta-1}{\theta}}+\left(1-\omega^{*}\right)^{\frac{1}{\theta}}\left(Y_{F, t}\right)^{\frac{\theta-1}{\theta}}\right]^{\frac{\theta}{\theta-1}},
$$

where $\left(1-\omega^{*}\right)=(1-\omega)(1-\tau)^{\theta-1}$. A higher rate of transportation costs $\tau$, or an increase in the elasticity of substitution $\theta$ decreases the value of $\left(1-\omega^{*}\right)$, and raises the home bias in the economy. In the Bayesian estimation of the model we fix the parameter $\omega$ and then estimate $\tau$ and $\theta$. The price level for the final good is:

$$
P_{t}=\left[\omega\left(P_{H, t}\right)^{1-\theta}+(1-\omega)\left(P_{F, t} /(1-\tau)\right)^{1-\theta}\right]^{\frac{1}{1-\theta}},
$$

where $P_{H, t}$ and $P_{F, t}$ denote the prices of the domestic and foreign intermediate goods. 


\subsubsection{Intermediate Goods Producers}

In each country, there is a continuum of intermediate differentiated goods producers, each producing a type of good that is an imperfect substitute of the others, using domestic capital and labor. The elasticity of substitution across types of goods is $\varepsilon_{p}$. These differentiated goods are sold to the composite intermediate goods producers.

Technology The production function of each intermediate good $h$ in the home country is given by

$$
Y_{t}(h)=\left[A_{t} N_{t}(h) X_{t}\right]^{1-\alpha}\left[K_{t-1}(h)\right]^{\alpha},
$$

where $\alpha$ is the share of capital in the production function. The above production function has two technology shocks. The first one, $X_{t}$, is a unit-root world technology shock that affects the two countries the same way. In addition, there is a labor-augmenting country specific technology shock, $A_{t}$, that evolves as a zero-mean, $\mathrm{AR}(1)$ process in logs.

Nominal Price Rigidities and Local Currency Pricing Once they have solved for the optimal capital-output ratio and cost minimization, intermediate good producers choose the price that maximizes discounted profits subject to a Calvo-type restriction. In our baseline model, we assume local currency pricing (LCP) for goods that are shipped internationally: with probability $1-\theta_{H}$ a firm chooses a price for the domestic market and a price for the foreign market, each price quoted in the destination market currency. Hence, there is price stickiness in each country's imports prices in terms of local currency, and the law of one price (excluding iceberg costs) holds in the steady state, but not outside of it. Additionally, we assume that the prices of each firm that cannot reoptimize in a given period is indexed to last period's inflation rate in each destination market with coefficient $\lambda_{H}$. Therefore, the coefficients of the two Phillips curves for each country (domestic inflation and exports inflation) have the same coefficients $\left(\theta_{H}, \lambda_{H}\right)$, but they differ across countries. In the foreign country, foreign inflation and imports inflation are governed by parameters $\left(\theta_{F}^{*}, \lambda_{F}^{*}\right)$. 


\subsection{Closing the Model}

In order to close the model, we impose market-clearing conditions for all types of home and foreign intermediate goods. For all aggregate intermediate goods, we need to take into account the size of the countries and the transportation costs. A fraction $\tau$ of the exports is assigned to the transportation sector and the rest is demanded by the foreign country. For the final good, the market clearing condition in the home country is the usual:

$$
Y_{t}=C_{t}+I_{t}+G_{t}
$$

We introduce an exogenous demand shock for each country $\left(G_{t}, G_{t}^{*}\right)$ which can be interpreted as government expenditure shocks that evolve as $A R(1)$ processes in logs. We assume that both governments run a balanced budget every period (i.e. $G_{t}=T_{t}$ and $G_{t}^{*}=T_{t}^{*}$ ). Finally, we assume that both countries follow a monetary policy rule that targets deviations of domestic CPI inflation and real GDP growth from their steady-state values, that we normalize to zero:

$$
\frac{R_{t}}{R}=\left(\frac{R_{t-1}}{R}\right)^{\varphi_{R}}\left[\left(P_{t} / P_{t-1}\right)^{\varphi_{\pi}}\left(G D P_{t} / G D P_{t-1}\right)^{\varphi_{y}}\right]^{1-\varphi_{R}} \exp \left(\varepsilon_{t}^{m}\right),
$$

where $\varepsilon_{t}^{m}$ is an iid monetary policy shock.

\section{Bayesian Estimation}

\subsection{Data}

We estimate the model using quarterly data for the U.K. and the euro area, between 1971 and 2008. The end-date is convenient to avoid the period of zero interest rates and unconventional monetary policy measures in the U.K., for which our model cannot provide a good characterization. We use six domestic macroeconomic series per country, and the bilateral real exchange rate, making a total of 13 observable variables. For each country we use: real per capita GDP growth, real per capita consumption growth, real per capita investment growth, real wage growth, CPI inflation and a short-term interest rate.

Our data sources are as follows. For the euro area, we obtain real GDP, real consumption, real investment, real wages, the Harmonized Index of Consumer Prices (HICP), and the short-term interest from the ECB's Area Wide 
Model (AWM). We obtain population series from Eurostat. Since this series is annual, we use linear interpolation to transform it to quarterly frequency. For the U.K. we obtain national accounts data (real GDP, real consumption and real investment) from the Office for National Statistics. The relevant measure for consumer prices is the Retail Price Index (RPI), obtained from the Office for National Statistics. This series provides a longer time span than the HICP (which is only available since 1995). For nominal wages, we use average earnings for the whole economy (including bonus), also produced by the Office for National Statistics. We compute real wages as nominal wages divided by the RPI. We use the Bank of England's Repo Rate as a measure of short-term interest rates. Population for the U.K. is also obtained through Eurostat, and transformed to quarterly frequency using linear interpolation. Finally, for the bilateral measures, we construct the real exchange rate of the U.K. pound sterling against the euro using the nominal exchange rate in U.K. pounds per euro, and multiplying it by the HICP of the euro area and dividing it by the RPI of the U.K.

\subsection{Model Dynamics and Data Transformations}

Since we have assumed that the model has a world technology shock with a stochastic trend, then real output, consumption, capital, investment, real wages, and the level of government spending inherit the same property and are non-stationary in levels. In order to render these variables stationary in the model, we divide them by the level of world technology. Real marginal costs, hours, inflation, interest rates, the real exchange rate and all other international relative prices are stationary. We obtain the model's dynamics by taking a log-linear approximation to the steady state values with normalized variables, zero inflation and balanced trade. We denote by lower case variables percent deviations from steady state values. Moreover, variables with a tilde have been normalized by the level of world technology to render them stationary. For instance, for consumption, $\widetilde{c}_{t}=\frac{\widetilde{C}_{t}-\widetilde{C}}{\widetilde{C}}$, where $\widetilde{C}_{t}=\frac{C_{t}}{X_{t}}$.

To estimate the model, we transform the series as follows. Since the model has a productivity shock with a stochastic trend, real variables are non-stationary in the model, but first-differencing makes them stationary. We apply the same treatment to their counterparts in the set of observable variables, which is also enough to make them stationary. The relationship between the same variable in the transformed model and in the data is as 
follows. For real consumption, for example:

$$
\Delta \widetilde{c}_{t}=\Delta c_{t}-\varepsilon_{t}^{x}
$$

where $\Delta \widetilde{c}_{t}$ is consumption growth in the model and $\Delta c_{t}$ is consumption growth in the data. The same reasoning applies to all other real variables. To compute per capita real GDP, consumption and investment growth rates we take logs and first differences of the raw (per capita) data. To compute real wage growth rates we also take logs and first differences.

To compute inflation rates we also take logs and first differences of the relevant price level series. We use nominal interest rates in levels because they are a stationary variable in the model and in the data. To make interest rates quarterly, we divide them by 400 . We use as observable variable the bilateral real exchange rate in logs and first differences. We demean all variables prior to estimation.

Let $\Omega$ denote the vector of parameters that describe preferences, technology, the monetary policy rules, and the shocks in the two countries of the model. The vector of observable variables consists of $\varkappa_{t}=\left\{\Delta g d p_{t}, \Delta g d p_{t}^{*}\right.$, $\left.\Delta c_{t}, \Delta c_{t}^{*}, \Delta i_{t}, \Delta i_{t}^{*}, \Delta p_{t}, \Delta p_{t}^{*}, \Delta\left(w_{t}-p_{t}\right), \Delta\left(w_{t}^{*}-p_{t}^{*}\right), r_{t}, r_{t}^{*}, \Delta r e r_{t}\right\}$. The home country is the U.K. and the foreign country is the euro area. Hence all variables and parameters with a star belong to the euro area. We express all variables as deviations from their sample mean. We denote by $L\left(\left\{\varkappa_{t}\right\}_{t=1}^{T} \mid \Omega\right)$ the likelihood function of $\left\{\varkappa_{t}\right\}_{t=1}^{T}$.

\subsection{Estimation: Priors and Posteriors}

We employ standard Bayesian estimation techniques (An and Schorfheide, 2007 ). We specify priors over the model's parameters $\Pi(\Omega)$ and obtain the posterior distribution of the parameters $\mathcal{P}\left(\Omega \mid\left\{\varkappa_{t}\right\}_{t=1}^{T}\right)$ using the MetropolisHastings algorithm with 125,000 draws. To reduce the number of parameters to be estimated, we fix a few parameters that are weakly identified with the set of observable variables (see Table 1). 


\begin{tabular}{lll}
\hline \hline & Value & Parameter \\
\hline$\beta$ & 0.99 & Discount factor \\
$\delta$ & 0.025 & Depreciation rate \\
$\alpha$ & 0.36 & Capital share on the production of intermediate goods \\
$\psi$ & 1 & Investment adjustment cost \\
$\varepsilon_{w}$ & 6 & Elasticity of substitution across types of labor \\
$\varepsilon_{p}$ & 11 & Elasticity of substitution across types of goods \\
$g / y$ & 0.2 & Fraction of government spending in GDP \\
$\omega$ & 0.9 & Degree of home bias in the U.K. \\
$\omega^{*}$ & 0.975 & Degree of home bias in the E.M.U. \\
$n$ & 0.2 & Size of the U.K. \\
\hline \hline
\end{tabular}

We set the discount factor to $\beta=0.995$. The depreciation rate, $\delta$, is set equal to 0.025 per quarter, which implies an annual depreciation on capital equal to 10 percent. We set $\alpha$ equal to 0.36 . We set the adjustment cost of investment, $\psi$, equal to 1 , a standard value in the literature. ${ }^{18}$ We set the elasticity of substitution across types of labor, $\varepsilon_{w}$, and across types of goods, $\varepsilon_{p}$, equal to 6 and 11, respectively, as it is standard in the DSGE literature. We set the steady-state ratio of government expenditures over GDP, equal to 0.2 . We set the fraction of imported goods, $1-\omega$, equal to 0.10 , which is in line with the imports for the EMU/GDP ratio in the U.K. We set the size of the U.K. economy to 0.2 , based on the relative GDP sizes. Finally, we calibrate $\omega^{*}$, such that given the values of $\omega$ and $n$, trade between the U.K. and the euro area is balanced. This value is quite similar to the ratio of imports from U.K./euro area GDP in the data.

\footnotetext{
${ }^{18}$ We estimated a version of the model where $\psi$ was estimated with a prior mean of 1 . The prior and posterior looked very much alike, suggesting that this parameter was not identified.
} 
Table 2: Prior distributions

\begin{tabular}{llccc}
\hline \hline Parameters & Description & & Mean & Std. Dev. \\
\hline$b, b^{*}$ & Habit persistence & Gamma & 0.7 & 0.05 \\
$\eta, \eta^{*}$ & Labor disutility & Gamma & 1.0 & 0.25 \\
$\theta$ & Elast. subst. between goods & Normal & 1.5 & 0.25 \\
$\chi$ & Cost of foreign position & Gamma & 0.02 & 0.014 \\
$\tau$ & Cost of shipping goods & Gamma & 0.10 & 0.05 \\
$\theta_{H}, \theta_{F^{*}}$ & Calvo lotteries in prices & Beta & 0.66 & 0.1 \\
$\lambda_{H}, \lambda_{F^{*}}$ & Indexation & Beta & 0.50 & 0.2 \\
$\theta_{w}, \theta_{w^{*}}$ & Calvo lotteries in wages & Beta & 0.75 & 0.1 \\
$\varphi_{\pi}, \varphi_{\pi^{*}}$ & Taylor rule Inflation & Normal & 1.5 & 0.25 \\
$\varphi_{y}, \varphi_{y^{*}}$ & Taylor rule output growth & Normal & 1.0 & 0.2 \\
$\varphi_{R}, \varphi_{R^{*}}$ & Interest rate smoothing & Beta & 0.5 & 0.28 \\
\hline$\rho_{c}, \rho_{c^{*}}, \rho_{n}, \rho_{n^{*}}, \rho_{v}, \rho_{v^{*}}$, & AR(1) coefficients of shocks & Beta & 0.75 & 0.2 \\
$\rho_{a}, \rho_{a^{*}}, \rho_{g}, \rho_{g^{*}, \rho_{u i p}}$ & & & & \\
\hline & Standard Deviation of Shocks & & & \\
$\sigma\left(\varepsilon_{t}^{i}\right), i=c, c^{*}, n, n^{*}$ & Preference & Gamma & 1.0 & 0.5 \\
$\sigma\left(\varepsilon_{t}^{i}\right), i=v, v^{*}, a, a^{*}$ & Investment and TFP & Gamma & 0.7 & 0.3 \\
$\sigma\left(\varepsilon_{t}^{i}\right), i=g, g^{*}$ & Government Spending & Gamma & 1.0 & 0.5 \\
$\sigma\left(\varepsilon_{t}^{x}\right)$ & TFP Unit root shock & Gamma & 0.7 & 0.3 \\
$\sigma\left(\varepsilon_{t}^{u i p}\right)$ & Uncovered Interest Parity & Gamma & 1.0 & 0.5 \\
$\sigma\left(\varepsilon_{t}^{i}\right), i=m, m^{*}$ & Monetary & Gamma & 0.4 & 0.2 \\
\hline \hline
\end{tabular}

The remaining parameters are estimated. Table 2 gives an overview of the prior distribution of the estimated parameters, that we denote by $\Pi(\Omega)$. We use Beta distributions for parameters bounded between 0 and 1 . For parameters assumed to be positive we use a Gamma distribution, and for unbounded parameters we use normal distributions. We center the priors to values that are typically used in calibrated exercises, or in previous estimations (such as Smets and Wouters, 2003, for the euro area). For the transportation costs we set $\tau=0.10$ as the mean prior, which is the estimate of transportation costs for the U.S. calculated by Feenstra (1996) and Hummels (2001).

Posterior distributions for the structural parameters of the benchmark economy are shown in Table 3, while Table 4 presents the posterior distributions related to the AR(1) coefficients and standard deviations of the shocks. Most parameter estimates are very similar to previous studies, in particu- 
lar those of the euro area, so we briefly comment on them. ${ }^{19}$ Interestingly, parameter estimates are not so different across the U.K. and the euro area, suggesting that the economic structures are quite similar. This similarity implies low costs of adopting a common currency. On the other hand, the parameters of the shock processes are quite different, which suggests that if they were to remain the same after a possible monetary union, then the costs of not being able to respond to domestic shocks and allow the exchange rate to absorb foreign shocks would be quite high.

The estimated posterior mean of the parameter $\chi$, that measures the elasticity of the interest rate premium with respect to net foreign assets is quite low, 0.0024, and hence suggests that the U.K. and the euro area enjoy a high degree of financial integration. For instance, Rabanal and Tuesta (2010) found an estimate between the U.S. and the euro area of 0.01 and for emerging economies García-Cicco et al. (2010) find a value close to 3. Next, we find that the elasticity of substitution between home and foreign goods is below but close to one, with a posterior mean of 0.89 . Finally, the parameter measuring shipping costs of all sorts due to international trade has a posterior mean of 0.089 . This estimate implies that almost 9 percent of the value of the goods traded internationally are spent on transportation and other transaction costs.

The posterior mean estimates for the external habit formation parameters are roughly in line with previous studies $(b=0.66$ for the U.K. and 0.57 for the euro area), while the same holds for the inverse elasticities of labor supply $\left(\eta=0.94\right.$ and $\left.\eta^{*}=0.92\right)$. Our point estimates imply stronger nominal rigidities in wage-setting than in price-setting: the posterior mean for the Calvo lottery for price setting implies that prices are reset on average every 2 quarters, while wages are reset every 4 quarters both in the U.K. and in the euro area. These estimates are somewhat lower than in Smets and Wouters (2003) for the euro area. The posterior mean of the price indexation parameter is much smaller than the mean value of the prior distribution, and makes backward looking behavior negligible. Estimates of the Taylor rules are also similar to what has been obtained in previous studies. We remark once more that the parameter estimates are very similar across countries, and hence the costs of monetary union would be coming from losing the capacity to react to domestic and foreign shocks rather than differences in the policy reaction functions.

\footnotetext{
${ }^{19}$ See Adolfson et al. (2007) and Rabanal and Tuesta (2010).
} 


\begin{tabular}{cccc}
\hline \hline$b$ & 0.66 & $b^{*}$ & 0.57 \\
& $(0.58-0.75)$ & & $(0.52-0.63)$ \\
$\eta$ & 0.94 & $\eta^{*}$ & 0.92 \\
& $(0.85-1.05)$ & & $(0.85-1.00)$ \\
$\theta_{H}$ & 0.50 & $\theta_{F}^{*}$ & 0.52 \\
& $(0.43-0.58)$ & & $(0.46-0.58)$ \\
$\lambda_{H}$ & 0.16 & $\lambda_{F}^{*}$ & 0.12 \\
& $(0.02-0.30)$ & & $(0.01-0.23)$ \\
$\theta_{w}$ & 0.78 & $\theta_{w}^{*}$ & 0.79 \\
& $(0.68-0.87)$ & & $(0.70-0.88)$ \\
$\varphi_{\pi}$ & 1.06 & $\varphi_{\pi}^{*}$ & 1.15 \\
& $(1.01-1.12)$ & & $(1.11-1.19)$ \\
$\varphi_{y}$ & 0.75 & $\varphi_{y}^{*}$ & 0.54 \\
& $(0.60-0.89)$ & & $(0.42-0.67)$ \\
$\varphi_{R}$ & 0.75 & $\varphi_{R}^{*}$ & 0.78 \\
$\theta$ & $(0.72-0.78)$ & & $(0.75-0.81)$ \\
$\theta$ & 0.89 & $\chi$ & 0.002 \\
$\tau$ & $(0.80-0.98)$ & & $(0.0001-0.004)$ \\
& 0.089 & & \\
\hline \hline
\end{tabular}

Table 4. Posterior distributions, shocks parameters

\begin{tabular}{|c|c|c|c|c|c|c|c|}
\hline$\rho_{c}$ & $\begin{array}{c}0.39 \\
(0.19-0.58)\end{array}$ & $\rho_{c^{*}}$ & $\begin{array}{c}0.97 \\
(0.96-0.99)\end{array}$ & $\rho_{a}$ & $\begin{array}{c}0.92 \\
(0.87-0.98)\end{array}$ & $\rho_{a^{*}}$ & $\begin{array}{c}0.99 \\
(0.99-0.99)\end{array}$ \\
\hline$\rho_{n}$ & $\begin{array}{c}0.76 \\
(0.68-0.84)\end{array}$ & $\rho_{n^{*}}$ & $\begin{array}{c}0.98 \\
(0.96-0.99)\end{array}$ & $\rho_{g}$ & $\begin{array}{c}0.89 \\
(0.85-0.93)\end{array}$ & $\rho_{g^{*}}$ & $\begin{array}{c}0.96 \\
(0.94-0.98)\end{array}$ \\
\hline$\rho_{v}$ & $\begin{array}{c}0.47 \\
(0.34-0.60) \\
\end{array}$ & $\rho_{v^{*}}$ & $\begin{array}{c}0.96 \\
(0.93-0.99) \\
\end{array}$ & $\rho_{\text {uip }}$ & $\begin{array}{c}0.92 \\
(0.88-0.96) \\
\end{array}$ & & \\
\hline$\sigma\left(\varepsilon_{t}^{c}\right)$ & $\begin{array}{c}3.34 \\
(2.55-4.04)\end{array}$ & $\sigma\left(\varepsilon_{t}^{c^{*}}\right)$ & $\begin{array}{c}1.92 \\
(1.40-2.44)\end{array}$ & $\sigma\left(\varepsilon_{t}^{a}\right)$ & $\begin{array}{c}2.37 \\
(1.94-2.80)\end{array}$ & $\sigma\left(\varepsilon_{t}^{a^{*}}\right)$ & $\begin{array}{c}1.36 \\
(1.15-1.59)\end{array}$ \\
\hline$\sigma\left(\varepsilon_{t}^{n}\right)$ & $\begin{array}{c}6.88 \\
(5.56-8.19)\end{array}$ & $\sigma\left(\varepsilon_{t}^{n^{*}}\right)$ & $\begin{array}{c}3.51 \\
(2.70-4.27)\end{array}$ & $\sigma\left(\varepsilon_{t}^{g}\right)$ & $\begin{array}{c}5.69 \\
(5.20-6.17)\end{array}$ & $\sigma\left(\varepsilon_{t}^{g^{*}}\right)$ & $\begin{array}{c}1.73 \\
(1.56-1.90)\end{array}$ \\
\hline$\sigma\left(\varepsilon_{t}^{v}\right)$ & $\begin{array}{c}4.76 \\
(4.19-5.31)\end{array}$ & $\sigma\left(\varepsilon_{t}^{v^{*}}\right)$ & $\begin{array}{c}1.04 \\
(0.91-1.15)\end{array}$ & $\sigma\left(\varepsilon_{t}^{m}\right)$ & $\begin{array}{c}0.36 \\
(0.31-0.40)\end{array}$ & $\sigma\left(\varepsilon_{t}^{m^{*}}\right)$ & $\begin{array}{c}0.21 \\
(0.18-0.24)\end{array}$ \\
\hline$\sigma\left(\varepsilon_{t}^{u i p}\right)$ & $\begin{array}{c}0.32 \\
(0.17-0.47)\end{array}$ & $\sigma\left(\varepsilon_{t}^{x}\right)$ & $\begin{array}{c}0.36 \\
(0.18-0.54)\end{array}$ & & & & \\
\hline
\end{tabular}

Table 4 shows that the shocks processes are quite different across countries. In particular, preference shocks and investment-specific shocks are more persistent in the euro area than in the U.K., while the innovations to the shocks are larger in the U.K. for those shocks. The TFP and government spending shock processes are quite similar across countries, while monetary policy shocks are fifty percent more volatile in the U.K. than in the euro area. In order to better understand how well the model fits the data and what shocks in the model drive which variables, Table 5 presents posterior 
distributions for the standard deviation of the observable variables implied by the model, as well as their variance decomposition. In the data, the U.K. is more volatile than the euro area. In particular, real per capita consumption and GDP growth is twice as volatile than in the euro area, while investment is almost four times as much. Inflation, real wage growth and nominal interest rate are also more volatile in the U.K. than in the euro area. The model is able to replicate these facts qualitatively, although it overpredicts the volatility of some real variables, in particular real GDP growth in both countries, investment in the euro area, and the real exchange rate.

Next, we analyze which shocks drive the behavior of the main variables (Table 5). We have aggregated the shocks as: supply (including TFP and investment-specific technology shocks in both countries), preference (intertemporal and intratemporal shocks in both countries), government spending, monetary (also aggregated across countries), and the UIP shock. First, we find the usual "exchange rate disconnect", in the sense that RER fluctuations are driven by the UIP shock (63.6 percent of its variance is driven by this shock), while the UIP shock explains very little of the volatility of all other macro variables. Supply disturbances explain about 19.2 percent of the volatility of the RER, while monetary shocks explain about 10 percent. Second, monetary policy shocks explain an important fraction of the variance of inflation (about 18 percent in both the U.K. and the euro area), and they explain also about 10 percent of the volatility of real GDP, consumption and investment growth in the euro area. The importance of monetary policy shocks in explaining the volatility of real variables in the U.K. is smaller (around 5 percent). Third, government spending shocks represent a significant fraction of real GDP growth volatility in the U.K. (22.4 percent) while they are a smaller fraction in the euro area.

Finally, it is worth mentioning that each variable is primarily driven by one or two types of shock. For instance, investment is driven mostly by investment-specific technology shocks, consumption is driven by the intertemporal preference shock, and real wages are driven by the TFP and the intratemporal preference shock. These results are consistent with other DSGE model estimations such as Justiniano et al. (2010) and Rabanal and Tuesta (2010). While not shown explicitly in Table 5 , the fraction of variance for each variable explained by shocks in the other country is always negligible: the international transmission of shocks is fairly small in the model. 


\begin{tabular}{|c|c|c|c|c|c|c|c|}
\hline \multicolumn{3}{|c|}{ Standard Deviations } & \multicolumn{5}{|c|}{ Variance Decompositions } \\
\hline & Data & Model & Supply & Pref. & Govt. Sp. & Mon. & UIP \\
\hline$\Delta g d p$ & 0.94 & $\begin{array}{c}1.83 \\
(1.71-1.93)\end{array}$ & 56.7 & 13.6 & 22.4 & 6.7 & 0.4 \\
\hline$\Delta g d p^{*}$ & 0.59 & $\begin{array}{c}0.93 \\
(0.85-1.01)\end{array}$ & 47.3 & 31.7 & 8.0 & 12.9 & 0.1 \\
\hline$\Delta c$ & 1.07 & $\begin{array}{c}1.28 \\
(1.16-1.37)\end{array}$ & 14.1 & 75.3 & 2.8 & 6.6 & 1.2 \\
\hline$\Delta c^{*}$ & 0.56 & $\begin{array}{c}0.85 \\
(0.80-0.91)\end{array}$ & 41.2 & 46.1 & 2.8 & 9.7 & 0.2 \\
\hline$\Delta i$ & 5.61 & $\begin{array}{c}5.94 \\
(5.36-6.41)\end{array}$ & 84.0 & 9.3 & 1.1 & 4.0 & 1.7 \\
\hline$\Delta i^{*}$ & 1.37 & $\begin{array}{c}2.31 \\
(2.05-2.52)\end{array}$ & 56.7 & 31.5 & 0.4 & 10.5 & 0.7 \\
\hline$\Delta p$ & 1.38 & $\begin{array}{c}1.52 \\
(1.27-1.71)\end{array}$ & 50.7 & 15.5 & 10.2 & 18.6 & 5.0 \\
\hline$\Delta p^{*}$ & 1.23 & $\begin{array}{c}0.96 \\
(0.79-1.08)\end{array}$ & 34.2 & 45.2 & 2.7 & 17.3 & 0.5 \\
\hline$\Delta(w-p)$ & 1.11 & $\begin{array}{c}1.09 \\
(0.98-1.18)\end{array}$ & 46.7 & 48.9 & 0.7 & 0.4 & 3.3 \\
\hline$\Delta\left(w^{*}-p^{*}\right)$ & 1.07 & $\begin{array}{c}0.68 \\
(0.62-0.73)\end{array}$ & 65.4 & 33.0 & 0.4 & 0.6 & 0.5 \\
\hline$r$ & 0.89 & $\begin{array}{c}1.01 \\
(0.77-1.21)\end{array}$ & 55.9 & 13.5 & 19.5 & 3.6 & 7.6 \\
\hline$r^{*}$ & 0.86 & $\begin{array}{c}0.84 \\
(0.64-1.01)\end{array}$ & 31.1 & 62.6 & 3.9 & 1.9 & 0.4 \\
\hline$\Delta($ rer $)$ & 3.32 & $\begin{array}{c}4.39 \\
(3.87-4.76)\end{array}$ & 19.2 & 6.6 & 0.7 & 9.9 & 63.6 \\
\hline
\end{tabular}

Note: "Supply" includes TFP and IST shocks, "Pref." includes intertemporal and intratemporal utility shocks.

\section{Policy Analysis: Welfare Gains of Entering a Monetary Union}

This section uses the estimated model to evaluate under what conditions will the U.K. benefit from joining the euro area. As we discussed in the introduction, we emphasize three factors that will impact the welfare of households in the U.K.:

1. The loss of independent monetary policy in a monetary union: entering a monetary union increases output and inflation volatility because 
monetary conditions in the EMU as a whole will not generally fit U.K. needs. The additional volatility generated by losing an independent monetary policy results in welfare losses.

2. The increase of trade due to lower transaction costs: the empirical literature finds that there is an expansion in trade for the country that joins a currency area (Rose, 2008). It is not clear what the precise magnitude of this trade expansion is. In the welfare analysis, we model the trade expansion as a reduction in trade costs. In our model, this reflects all possible transactions costs related to trade. This is a steadystate effect that will increase consumption and production in the U.K. Its effects on volatility are quantitatively very small.

3. Changes in the behavior of UIP shocks that can occur in a monetary union. If one where to study the behavior of the UIP shock between 1999-2007 for those countries in the euro area, one would conclude that these shocks are fairly small. But the experience since 2007 is that we cannot rule out the presence of this shock, and both the level and the volatility cannot be assumed to be zero after EMU membership. If either the mean or the volatility this shock increase, welfare will be affected negatively in the U.K.

We adopt a conservative approach and assume that the transaction costs (or "iceberg costs" as defined in section 2) drop by 5 percentage points. This value is at the lower end of estimated trade costs reductions for joining the EMU (see Anderson and van Wincoop, 2004). We calibrate the change in the mean and variance of the risk premium, assuming that the U.K. will experience an increase in the risk premium similar to the average of France, Italy, and Spain. Excluding Germany, these economies are the largest in the euro area, and are close in size to the U.K. ${ }^{20}$ Since there is high uncertainty about how trade costs and the risk premium will behave for the U.K. once it enters the EMU, we conduct an extensive sensitivity analysis for alternative parameter values in section 6 .

\footnotetext{
${ }^{20}$ An alternative scenario for the U.K. is one in which its financial assets are considered as a safe haven by international investors and the risk premium declines. We evaluate the impact of this scenario on welfare in the sensitivity analysis section.
} 
We calculate the welfare gains of joining a monetary union following the same approach by Lucas (1987). Given a set of allocations $\left\{C_{t}^{k}, N_{t}^{k}\right\}_{t=0}^{\infty}$ for $k=I, M U$, where $I$ is the allocation under the independent monetary policy and $M U$ the allocation under the monetary union, the welfare gain $\gamma$ is calculated as follows: ${ }^{21}$

$$
E\left[\sum_{t=0}^{\infty} \beta^{t} u\left((1+\gamma) C_{t}^{I}, N_{t}^{I}\right)\right]=E\left[\sum_{t=0}^{\infty} \beta^{t} u\left(C_{t}^{M U}, N_{t}^{M U}\right)\right]
$$

If the resulting parameter $\gamma$ is positive, then there are net gains from entering a monetary union. On the other hand if $\gamma<0$, then a country is better off following an independent monetary policy. We calculate the welfare gain $\gamma$ for two cases. First, we calculate the welfare gain at the steady state to understand the long-run effects of joining a currency area. Second, we measure the effects of changes in the business cycle (i.e. volatility of main variables) on welfare.

Table 6 shows the steady-state effects and welfare gains of joining a currency area under lower trade costs and under increased financial turbulence. In the first column, we show the steady state values, which are normalized to 100, under the current situation (independent monetary policy and flexible exchange rate). In the second column, we show the long-run effect of lower transaction costs. The overall effect is an increase in welfare of 1.2 percentage points of life-time consumption. The reduction of trade costs has several effects in the economy. First, it allows the U.K. economy to trade more: the reduction of trade costs leads to an increase in 0.2 percentage points in both exports and imports. Second, households have more resources available due to lower transaction costs, and hence consumption will be higher. Also, as a result of wealth effects, labor supply will decrease. Third, lower distortions will lead to higher investment, capital stock and GDP. The impact on consumption and leisure determines an increase in welfare at the steady state. Finally, the U.K. enjoys a safe haven status where the average risk premium is zero.

The third column of Table 6 illustrates the case of financial turbulence by assuming an increase of the average UIP shock by 40 basis points (quarterly). This is the difference in the interest rate spread of the U.K. and the average of France, Italy, and Spain for the (crisis) 2008-2011 period. This scenario is

\footnotetext{
${ }^{21}$ The welfare cost estimate comes from the unconditional expected lifetime utility, and is calculated up to a second order approximation following Schmitt-Grohé and Uribe (2007).
} 
intended to evaluate the impact of adopting a common currency in times of financial stress, and for which there would be no use of unconventional monetary policy in the U.K. There are several effects of a higher mean of the UIP shock. First, higher interest rates affect negatively the decision on consumption and investment, which lead to a decline in GDP. Second, the negative wealth effect increases labor supply, but the effect is quantitatively small. Finally, the decline in real wages leads to a real exchange rate depreciation, which in turn increases exports and reduces imports.

Table 6. Steady State Effects and Welfare Gains

\begin{tabular}{lccc}
\hline \hline \multicolumn{1}{c}{ Variables in Levels } & Ind. M.P. & $\begin{array}{c}\text { M.U. } \\
\text { Low T.C. }\end{array}$ & $\begin{array}{c}\text { M.U. } \\
\text { High UIP. }\end{array}$ \\
\hline \hline & & & \\
Output $(g d p)$ & 100 & 100.71 & 99.93 \\
Consumption $(c)$ & 100 & 100.92 & 99.90 \\
Investment $(i)$ & 100 & 100.71 & 99.97 \\
Capital $(k)$ & 100 & 100.71 & 99.97 \\
Employment $(n)$ & 100 & 99.89 & 100.04 \\
Exports $(x)$ & 100 & 100.21 & 100.34 \\
Imports $(m)$ & 100 & 100.21 & 99.97 \\
& & & \\
Welfare Gains $(\lambda \times 100)$ & - & 1.20 & -0.21 \\
& & & \\
\hline
\end{tabular}

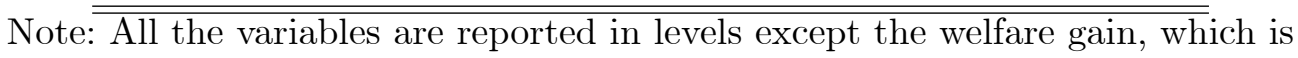
expressed as a percentage of steady state consumption. The macroeconomic variables with an independent monetary policy are normalized to 100 . "Ind M.P." means Independent Monetary Policy. "M.U." means Monetary Union. "Low T.C." means low transportation costs scenario.

These experiments illustrate the long-run effects of two possible scenarios after the adoption of a currency union. On the one hand, there are large positive effects coming from a reduction of trade costs, and a safe haven status. But, if the U.K. experiences higher financial turbulences, there would be negative effects associated with higher average interest rates. However, these results abstract from the cyclical effects of joining a currency union. Under a common currency, there is a loss of monetary independence and exchange rate flexibility, which limits the ability of a country to stabilize the 
cycle and respond to shocks. If the cycle is not perfectly synchronized with the rest of the member countries of the currency union, and wages and prices are sticky, then the adjustment will involve more macroeconomic volatility in real variables. This volatility effect can undermine the benefits derived from lower transaction costs or magnify costs of a higher UIP shock.

Table 7 shows the business cycle effects of alternative monetary and exchange rate policy arrangements. In the first column, we compute the volatility of main U.K. variables under the baseline model with both the ECB and the BoE following their estimated Taylor rules. Then, we compare this baseline scenario with four alternative policy scenarios. The second column shows the case when the U.K. joins the EMU and transaction costs remain high. In this case, there is an increase in volatility of most macroeconomic variables due to the fact there is no flexible nominal exchange rate and domestic interest rate policy to absorb country-specific shocks in the U.K. Only exports and real exchange rate volatility decline. In the model, the real exchange rate is less volatile because the external adjustment of the economy is done via prices, which adjust slowly overtime. A lower volatility of the exchange rate will also reduce the volatility of exports in the model. The welfare loss derived exclusively from entering the monetary union will be 0.3 percent of life-time consumption, which is fully explained by higher macroeconomic volatility. 


\begin{tabular}{lccccc}
\hline \hline \multicolumn{1}{c}{$\begin{array}{c}\text { Variables in First } \\
\text { Differences }\end{array}$} & Ind. M.P. & $\begin{array}{c}\text { M.U. } \\
\text { High T.C. }\end{array}$ & $\begin{array}{c}\text { M.U. } \\
\text { Low T.C. }\end{array}$ & $\begin{array}{c}\text { M.U. } \\
\text { Low UIP }\end{array}$ & $\begin{array}{c}\text { M.U. } \\
\text { High UIP }\end{array}$ \\
\hline \hline & & & & & \\
Output $(\Delta g d p)$ & 1.83 & 2.14 & 2.14 & 1.72 & 4.17 \\
Consumption $(\Delta c)$ & 1.28 & 1.51 & 1.51 & 1.29 & 2.67 \\
Investment $(\Delta i)$ & 5.94 & 7.20 & 7.20 & 5.87 & 13.78 \\
Capital $(\Delta k)$ & 0.61 & 0.68 & 0.68 & 0.59 & 1.17 \\
Employment $(\Delta n)$ & 3.07 & 3.66 & 3.66 & 3.06 & 6.74 \\
Exports $(\Delta x)$ & 3.19 & 1.38 & 1.38 & 1.17 & 2.45 \\
Imports $(\Delta m)$ & 1.98 & 2.42 & 2.42 & 1.91 & 4.86 \\
Consumer Price $(\Delta p)$ & 1.52 & 1.58 & 1.58 & 1.05 & 2.56 \\
Real Exchange Rate $(\Delta r e r)$ & 4.39 & 1.28 & 1.28 & 1.41 & 2.27 \\
Welfare Gains $(\lambda \times 100)$ & - & -0.26 & -0.26 & & \\
& & & & & \\
\hline \hline
\end{tabular}

See notes in Table 6 .

The third column of Table 7 shows the case when the U.K. joins the EMU, reducing transaction costs by 5 percentage points. Consistent with the work of Ravn and Mazzenga (2004), the cyclical effects of a reduction in transaction costs are very small in the model. ${ }^{22}$ The fourth column describes the situation in which the UIP shocks disappear once the U.K. joins the EMU. This scenario captures the episode of interest rate spreads compression observed in the period 1999-2007 for several EMU members, and would reflect that the U.K. becomes a safe haven with no risk premia. Removing UIP shocks reduces output growth volatility and leads to a welfare gain of 0.2 percent of life-time consumption. Finally, the fifth column shows the case when the U.K. enters the EMU in a situation of financial turbulence. We calibrated a situation of financial turbulence by increasing the standard deviation of UIP shocks three times. This scenario is consistent with what happened with France, Italy and Spain relative to the U.K. in the recent financial crisis. As a result, the volatility of domestic interest rates increases importantly, which transmits to most macroeconomic variables. The only

\footnotetext{
${ }^{22}$ The quantitative effects on business cycles are noticeable when the reduction in transaction costs is greater than 50 percent. With a reduction of only 5 percent, the results in columns 2 and 3 in table 7 are virtually the same.
} 
exception is the real exchange rate. As explained in the previous paragraph, lower exchange rate volatility can be explained by price rigidities which turns the external adjustment much more slower compared to the case of a flexible exchange rate. This scenario leads to a welfare loss of 3.9 percent of life-time consumption.

We have just studied the effects of UIP shocks and their detrimental effect on welfare when the U.K. joins the euro. But what are the dynamics of a UIP/interest rate spread shock when the U.K. does not enter the euro area? In Figure 4 we present the impulse-responses to a UIP shock, under an independent monetary policy with flexible exchange rates and under EMU membership. The effects are strikingly different. In panel $\mathrm{F}$ we observe that, in a monetary union, the UIP shock translates into an increase in the interest rate in the U.K., while in the case of an independent monetary policy the UIP shock affects both interest rates and exchange rates. Inside the EMU, the UIP shock acts as a monetary shock, and hence depresses output, employment and inflation (Panels A and B). On the contrary, under a flexible exchange rate, the UIP shock translates mostly into a depreciation of the currency, and to some interest rate increases. As a result, the overall effect on output and inflation is negligible. It is important to note that, in a monetary union, the depreciation process is more sluggish. Panel E shows that in fact, the real exchange rate devaluation in a monetary union is implemented with a deflation, a process that is typically described as an "internal devaluation". Clearly, if UIP shocks are important, enjoy exchange rate flexibility allows to offset their contractionary effects.

Table 8 summarizes the main results from this section combining the steady state and business cycle effects. First, in tranquil times and under lower transaction costs, there are positive gains from entering a monetary union of 0.9 percent of life-time consumption. Second, under financial turbulence the result is completely reversed, and belonging to a monetary union generates a net welfare loss of 2.9 percent. This stark difference in the results can help to rationalize the decision of the U.K. to postpone the entry to the EMU. During tranquil times the model indicates substantial benefits from adopting a currency, however under financial turbulence the gains disappear and the appropriate regime is to stay out of the EMU. 
Table 8. Summary of Welfare Gains

(Percentage points of life-time consumption)

\begin{tabular}{lcc}
\hline \hline & $\begin{array}{c}\text { Tranquil } \\
\text { Times }\end{array}$ & $\begin{array}{c}\text { Financial } \\
\text { Turbulence }\end{array}$ \\
\hline \hline Steady State Effects & 1.20 & 0.99 \\
\hline Trade Costs & 1.20 & 1.20 \\
Interest Rate Spread & -0.21 \\
& & \\
\hline Business Cycle Effects & -0.26 & -3.90 \\
\hline Monetary Union - Historical Shocks & -0.26 & \\
Monetary Union - Volatile Spread Shocks & & -3.90 \\
& & \\
\hline Aggregate Effects & 0.94 & -2.91 \\
\hline
\end{tabular}

\section{Sensitivity Analysis}

Given the uncertainty on how parameter values will behave before and after EMU membership, in this section we present some sensitivity analysis. As we discussed in the previous section, if the only change in environment is that the UK enters the EMU, there is a welfare loss of 0.26 percent of lifetime consumption, due to the loss of monetary and exchange rate policy. We consider the impact on welfare of changing some key parameters of the model in Figure 5, including: (i) a reduction in transaction costs, (ii) changes in the probability of a financial crisis, (iii) changes in the mean of the steadystate interest rate spread, (iv) changes in the standard deviation of the UIP shock, that affect the volatility of interest rates, (iv) changes in the degree of nominal price rigidities, and (vi) changes in the degree of wage rigidities.

Panel A shows welfare gains as a function of trade costs. Under the baseline scenario trade costs fall to 4 percent and the welfare gains of joining a monetary union are close to 1 percent. However, if after joining the currency area there is no reduction in trade costs, and these remain at 9 percent, then the U.K. will experiment a welfare loss of 0.26 percent of GDP. ${ }^{23}$ The cut-off

\footnotetext{
${ }^{23}$ Santos Silva and Tenreyro (2010) show that the euro effect on trade has been close to zero. Using their estimate our model will show a net welfare loss derived from entering a monetary union.
} 
point for a welfare improvement with respect to trade costs is 8 percent.

Panels $\mathrm{B}$ and $\mathrm{C}$ show the effects of changing the mean and the standard deviation of the UIP shock. Setting the mean of the UIP shock raises steadystate interest spreads by the same amount. Increasing interest rate spreads to 40 basis points increases the welfare costs but to a limited extent. On the other hand, a reduction in the mean spread (which could also be possible if financial markets view U.K. debt as safe haven) would lead to a positive welfare gain from entering the EMU. Panel D describes the impact of the volatility of UIP shocks on welfare. The quantitative effect of increasing the standard deviation of the UIP shock is much larger than increasing the mean. In the baseline model, the standard deviation of the UIP shock is 0.3 , and generates a welfare cost of 0.3 percentage point of life-time consumption. In an scenario similar to the recent crisis episode, the risk premium volatility increases 3 times then the welfare cost raises to 4 percent of life-time consumption.

Panel D shows the effects of changing the probability of a financial crisis on welfare. In the case where the probability is 1 , we obtain the same results as in the previous section and the net welfare costs on joining the monetary union are 2.9 percentage points of life-time consumption. As we reduce the probability of a crisis, then the welfare costs are lower. In the extreme case of having a zero probability of a financial crisis, that is a macroeconomic scenario for tranquil times, we obtain a net welfare gain of 0.9 percentage points of life-time consumption. When the probability of a crisis is 0.25 , then all the benefits of lower trade costs are fully offset by the costs of higher macroeconomic volatility, and the country is indifferent between joining a monetary union and adopting an independent monetary policy.

Panel E shows the effect of price stickiness on welfare. In the baseline model, the estimated Calvo parameter is close to 0.5 , which implies an average frequency of price adjustment of 2 quarters. Reducing the frequency of price adjustment in the economy does not increase welfare substantially, because in the baseline model price rigidities are small already. However, Panel $\mathrm{F}$ shows that there are larger welfare gains from reducing wage rigidities. In the baseline model, the wage rigidity Calvo parameter is close to 0.8, which implies a frequency of price adjustment greater than four quarters. Reducing the frequency to three quarters or less, can generate a positive welfare gain of EMU membership, even without assuming a reduction in trade costs.

In this section we described how the welfare analysis changes in response to difference assumptions on the parameters of the model. Two important 
results emerge from this analysis. First, the welfare gain from entering a monetary union can be completely eliminated with financial shocks similar in size and volatility to what has been observed in the recent financial crisis episode. Second, there are some potential gains from increasing labor market flexibility. If a government implement labor market reforms that increase the flexibility of the economy, it could more than compensate the lack of the nominal exchange rate adjustment over the business cycle.

\section{Conclusions}

This paper revisits the old issue of optimal currency areas. Since the seminal paper by Mundell (1961) on optimum currency areas, there has been an extensive research on benefits and costs of joining a monetary union. Even though a complete analysis of entering a currency union should include several dimensions in terms of the impact on growth and business cycles, we contributed to the discussion in two dimensions. First, we estimated a twocountry DSGE model of the U.K. and the euro area in order to use it as a laboratory to evaluate the welfare impact on the U.K. of adopting the euro. Second, we evaluate the role of trade and financial channels in the decision of entering a monetary union.

On the one hand, joining a currency union could reduce the transaction costs of trade with other countries, providing efficiency gains to the new member country and the monetary union as a whole. On the other hand, adopting a common currency is costly for a country since it loses independent monetary and exchange rate policies as tools for macroeconomic stabilization. The paper shows that when comparing these two channels only, the trade-off is resolved in favor of entering the euro area with a net welfare gain of 0.9 percentage points of life-time consumption.

However, the financial channel can radically change the welfare implications of entering a monetary union. Under the baseline parametrization, introducing financial shocks of the magnitude observed in the current financial crisis can eliminate any potential gain from lower trade costs. In particular, the welfare costs from an episode of financial turbulence is more than three times the welfare gains derived from lower trade costs. The policy analysis underscores the fact that financial stability, measured as low and stable risk premium, is of key importance to sustain a monetary union. Interest rate spread shocks might eliminate any potential gain from entering into a 
currency area.

Throughout the analysis, we have treated spread shocks as exogenous, but there are reasons to think that they are not. To the extent that spreads differ across countries because of different underlying fundamentals and as a discipline device, differences should be welcome. The increased financial turbulence in the EMU is likely to be a by-product of the design flaws in the creation of the single currency, and include failures in fiscal discipline, lax regulatory policies and a disregard for persistent current account imbalances in the EMU. Therefore, European policymakers should aim at reducing the incidence of these factors by ensuring that the right policies are implemented in the future. Also, during the crisis, the BoE has conducted unconventional monetary policies that reduced the level and volatility of U.K. long term rates. This capability would be lost if the U.K. entered the EMU, although the ECB has also provided ample liquidity in the markets through commercial banks using long-term refinancing operations (LTRO). Possibly, the way forward inside the EMU is to enforce the right policies to reduce financial turbulences in the markets and contagion, and to make sure that countries have enough fiscal space to conduct countercyclical fiscal policy in the midst of a crisis. The paper also illustrated how the lack of exchange rate adjustment in a monetary union can be more than compensated with wage flexibility. Introducing reforms in the labor market that ensure rapid wage adjustment over the cycle can also help to preserve the gains from a monetary union.

There are several interesting extensions for future research. First, we can consider the impact of uncertainty shocks into the model. Not only there is an impact on the risk premium, but also on uncertainty about the futures prospects of fiscal solvency. We could introduce volatility shocks to the interest rate as in Fernández-Villaverde et al. (2011) to measure the effects of uncertainty in the euro area. Second, we could model unemployment frictions. The sudden rise of unemployment during the great recession, and the subsequent slow recovery could be model through the Mortensen-Pissarides framework as in Shimer (2010). Finally, given the importance of financial services on the U.K. economy (around 10 percent of GDP), it would be useful to model explicitly the financial system to quantify the impact of entering the euro area. 


\section{A Appendix: The Model}

In this appendix we present the stochastic two country model that we will use to analyze linkages between the U.K. and the euro area. We estimate a twocountry version of a DSGE model similar to those by Christiano, Eichenbaum and Evans (2005) and Smets and Wouters (2003, 2007), where we include trade and financial linkages across countries. A similar two-country model has been estimated by Rabanal and Tuesta (2010) using data for the United States and the euro Area. As in that paper, our benchmark model assumes that there is local currency pricing for goods that are shipped internationally. In addition, we assume that there is an incomplete asset market structure at the international level: agents only have access to one non-contingent bond that is denominated in foreign-country currency. The model incorporates 14 shocks because in the econometric section we are interested in explaining 13 variables.

We assume that there are two countries, home and foreign, of sizes $n$ and $1-n$, respectively. Each country produces a continuum of intermediate goods, indexed by $h \in[0, n]$ in the home country and $f \in[n, 1]$ in the foreign country, which are traded internationally. Intermediate goods are imperfect substitutes for each other, and are priced according to a Calvo-type restriction. They are used as in input in the production of the final good that is used for domestic final consumption, investment, and government spending, and hence it is not traded across borders. The model also incorporates linear shipping costs of moving goods internationally. As it is typically done in the literature, we follow Samuelson (1954) and introduce "iceberg" shipping costs.

In what follows, we present the problem for households, intermediate goods producers, shipping firms, and final goods producers in the home country. The expression for the foreign country are analogous, and the convention we use is that variables and parameters with an asterisk denote the foreign country counterparts.

\section{A.1 Households}

In each country, there is a continuum of infinitely lived households in the unit interval, that obtain utility from consuming the final good and disutility from supplying hours of labor. In the home country, households are indexed by $j$ $\in[0, n]$ and their life-time utility function is: 


$$
E_{0} \sum_{t=0}^{\infty} \beta^{t} D_{c, t}\left[\log \left(C_{t}^{j}-b C_{t-1}\right)-D_{n, t} \frac{\left(N_{t}^{j}\right)^{1+\eta}}{1+\eta}\right],
$$

where $E_{0}$ denotes the rational expectations operator using information up to time $t=0 . \beta \in[0,1]$ is the discount factor. Consumers obtain utility from consuming the final good, $C_{t}^{j}$, with external habit formation. $b \in[0,1]$ denotes the importance of the habit stock, which is last period's aggregate consumption $\left(C_{t-1}\right) . \quad \eta>0$ is the inverse elasticity of labor supply with respect to the real wage, and $N_{t}^{j}$ is the labor supply of the household. $D_{c, t}$, and $D_{n, t}$ denote intertemporal and intratemporal preference shocks. ${ }^{24}$ These shocks evolve as follows:

$$
\begin{aligned}
\log \left(D_{c, t}\right) & =\rho_{c} \log \left(D_{c, t-1}\right)+\varepsilon_{t}^{c, d} \\
\log \left(D_{n, t}\right) & =\rho_{n} \log \left(D_{n, t-1}\right)+\varepsilon_{t}^{n, d}
\end{aligned}
$$

\section{A.1.1 International Asset Markets Structure and the Budget Con- straint}

Markets are complete within each country and incomplete at the international level. We introduce international incomplete markets in a simple and tractable way, following Benigno (2009). We assume that, in each country, domestic households have access to a nominal riskless bond that costs the inverse of the gross domestic nominal interest rate. Given the assumption of complete markets, this bond is redundant. In addition, there is an internationally traded bond that is denominated in foreign country currency, and that allows to engage in intertemporal international trade across countries. The budget constraint of home-country households is given by:

$$
\begin{aligned}
& P_{t}\left(C_{t}^{j}+I_{t}^{j}\right)+\frac{B_{t}^{j}}{R_{t}}+\frac{S_{t} D_{t}^{j}}{R_{t}^{*} \Psi\left(\frac{S_{t} D_{t}}{Y_{t} P_{t}}\right) U_{t}}+T_{t} \\
= & B_{t-1}^{j}+S_{t} D_{t-1}^{j}+W_{t}^{j} N_{t}^{j}+P_{t} R_{t}^{K} K_{t-1}^{j}+\Pi_{t}^{j}+\xi_{t}^{j},
\end{aligned}
$$

\footnotetext{
${ }^{24}$ See Primiceri et al. (2006).
} 
where $B_{t}^{j}$ and $D_{t}^{j}$ denote holdings of the domestic and foreign currency denominated bonds, $R_{t}$ is the home country gross nominal interest rate and $R_{t}^{*}$ is the foreign country gross nominal interest rate. $S_{t}$ is the nominal exchange rate expressed in units of domestic currency needed to buy one unit of foreign currency and $P_{t}$ is the price level of the final good (to be defined below). $T_{t}$ are lump-sum taxes that are used to finance government spending. $\xi_{t}^{j}$ denotes the payoff from engaging in trade of domestic statecontingent securities. ${ }^{25}$

Home-country households also face a cost of undertaking positions in the foreign bonds market. The $\Psi$ (.) function captures this cost and depends on the aggregate real holdings of the foreign assets in the entire economy, and therefore is taken as given by individual households. ${ }^{26}$ We also include an exogenous shock $\left(U_{t}\right)$ to the function $\Psi($.$) , which helps explains deviations$ from the uncovered interest rate parity condition. For this reason, we call this shock the "uncovered interest rate parity" shock, which also follows a zero mean, $\operatorname{AR}(1)$ process in logs.

Consumers obtain labor income from supplying labor to intermediate goods producers, for which they receive a nominal wage, $W_{t}^{j}$, and receive profits from intermediate and wholesale final goods producers $\Pi_{t}^{j}$. The model includes sticky wages, and hence the wage received by each household is specific and depends on the last time wages were reoptimized. The assumption of complete markets within each country allows to separate the consumption/saving decisions from the labor supply decision (see Erceg, Henderson, and Levin, 2000; henceforth EHL).

\section{A.1.2 Capital Accumulation and the Investment/Savings Deci- sion}

Households rent capital to the firms that produce intermediate goods. $K_{t-1}^{j}$ and $I_{t}^{j}$ denotes holdings of capital stock and investment purchases, respectively. The real rental rate of capital is denoted by $R_{t}^{K}$. The capital accumulation dynamics is given by the following expression

\footnotetext{
${ }^{25}$ In order to keep notation simple, we do not make the structure of the complete domestic asset markets explicit.

${ }^{26}$ This cost induces stationarity in the net foreign asset position. See Schmitt-Grohé and Uribe (2003) for applications in small open economy models, and Benigno (2009) in two-country models.
} 


$$
K_{t}^{j}=(1-\delta) K_{t-1}^{j}+V_{t}\left[1-S\left(\frac{I_{t}^{j}}{I_{t-1}^{j}}\right)\right] I_{t}^{j}
$$

Here, $\delta$ denotes the rate of depreciation and the adjustment cost function, $S\left(\right.$.), is an increasing and convex function (i.e. $\left.S^{\prime}(), S^{\prime \prime}()>0\right)$. Furthermore, in the steady state $\bar{S}=\bar{S}^{\prime}=0$ and $\bar{S}^{\prime \prime}>0$. The $S$ (.) function summarizes the technology that transforms current and past investment into installed capital for use in the following period. This expression also includes an investmentspecific technology shock $\left(V_{t}\right)$ that evolves as:

$$
\log \left(V_{t}\right)=\rho_{v} \log \left(V_{t-1}\right)+\varepsilon_{t}^{v} .
$$

The first order conditions for holding domestic and foreign bonds, capital and investment are:

$$
\begin{gathered}
1=\beta R_{t} E_{t}\left(\frac{C_{t}-b C_{t-1}}{C_{t+1}-b C_{t}} \frac{D_{c, t+1}}{D_{c, t}} \frac{P_{t}}{P_{t+1}}\right), \\
1=\beta R_{t}^{*} \Psi\left(\frac{S_{t} D_{t}}{P_{t} Y_{t}}\right) u_{t} E_{t}\left(\frac{C_{t}-b C_{t-1}}{C_{t+1}-b C_{t}} \frac{D_{c, t+1}}{D_{c, t}} \frac{S_{t+1} P_{t}}{S_{t} P_{t+1}}\right), \\
Q_{t}=\beta E_{t}\left\{\left(\frac{C_{t}-b C_{t-1}}{C_{t+1}-b C_{t}} \frac{D_{c, t+1}}{D_{c, t}}\right)\left[R_{t+1}^{K}+Q_{t+1}(1-\delta)\right]\right\}, \\
1-Q_{t} V_{t}\left[1-S\left(\frac{I_{t}}{I_{t-1}}\right)-\frac{I_{t}}{I_{t-1}} S^{\prime}\left(\frac{I_{t}}{I_{t-1}}\right)\right] \\
=\beta E_{t}\left(\frac{C_{t}-b C_{t-1}}{C_{t+1}-b C_{t}} \frac{D_{c, t+1}}{D_{c, t}}\right) Q_{t+1} V_{t+1}\left[S^{\prime}\left(\frac{I_{t+1}}{I_{t}}\right)\left(\frac{I_{t+1}}{I_{t}}\right)^{2}\right],
\end{gathered}
$$

where $Q_{t}$ is the shadow price of investment in terms of consumption goods, and where we have dropped all the superscripts, since by using the domestic complete markets assumption, all households in one country take the same decision. Combining equation (16) with the analogous to (15) in the foreign country delivers the following risk-sharing condition, which forms the basis of the real exchange rate determination under incomplete markets:

$$
E_{t}\left(\frac{C_{t}^{*}-b^{*} C_{t-1}^{*}}{C_{t+1}^{*}-b C_{t}^{*}} \frac{D_{c, t+1}^{*}}{D_{c, t}^{*}} \frac{P_{t}^{*}}{P_{t+1}^{*}}\right)=E_{t}\left(\frac{C_{t}-b C_{t-1}}{C_{t+1}-b C_{t}} \frac{D_{c, t+1}}{D_{c, t}} \frac{S_{t+1} P_{t}}{S_{t} P_{t+1}}\right) \Psi\left(\frac{S_{t} D_{t}}{Y_{t} P_{t}}\right) U_{t}
$$


We define the real exchange rate as the ratio of final goods prices, expressed in common currency:

$$
R E R_{t}=\frac{S_{t} P_{t}^{*}}{P_{t}}
$$

\section{A.1.3 Staggered Wage Setting and The Wage Decision}

As in EHL, we assume that the household is a monopoly supplier of differentiated labor service, $N_{t}^{j}$. It sells this service to a competitive firm that transforms it into an aggregate labor input that is used by the intermediate goods producers. Thus, one effective unit of labor that an intermediate goods producer firm, $h$, uses for production is given by

$$
N_{t}(h)=\left\{\left(\frac{1}{n}\right)^{\varepsilon_{w}} \int_{0}^{n}\left[N_{t}^{j}(h)\right]^{\frac{\varepsilon_{w}-1}{\varepsilon_{w}}} d j\right\}^{\frac{\varepsilon_{w}}{\varepsilon_{w}-1}}
$$

where $N_{t}^{j}(h)$ is the amount of labor supplied by household $j$ to firm $h$. As shown by EHL, the demand curve for each type of labor is given by

$$
N_{t}^{j}=\left(\frac{W_{t}^{j}}{W_{t}}\right)^{-\varepsilon_{w}} N_{t}, \text { for } j \in[0,1]
$$

where $W_{t}$ and $N_{t}$ are aggregate labor and wage indices as follows: $W_{t}=$ $\left[\frac{1}{n} \int_{0}^{n}\left(W_{t}^{j}\right)^{1-\varepsilon_{w}} d j\right]^{\frac{1}{1-\varepsilon_{w}}}, N_{t}^{j}=\frac{1}{n} \int_{0}^{n} N_{t}^{j}(h) d h$, and $N_{t}=\frac{1}{n} \int_{0}^{n} N_{t}(h) d h$.

Households set wages in a staggered way with a Calvo-type restriction. In each period, a fraction $1-\theta_{w}$ of households can reoptimize their posted nominal wage. Consider a household resetting its wage in period $t$, and let $W_{t}^{*}$ the newly set wage. The household will choose $W_{t}^{*}$ in order to maximize

$$
\underset{W_{t}^{*}}{\operatorname{Max}} E_{t} \sum_{k=0}^{\infty}\left(\beta \theta_{w}\right)^{k} D_{c, t+k}\left[\log \left(C_{t+k}-b C_{t+k-1}\right)-D_{n, t+k} \frac{\left(N_{t+k \mid t}\right)^{1+\eta}}{1+\eta}\right]
$$

where $N_{t+k \mid t}$ denotes labor supply in period $t+k$ of a household that last reset its wage in period $t$. Households maximize (23) subject to (13) and (22). The first order condition associated with the problem above can be expressed as follows: 
$E_{t} \sum_{k=0}^{\infty}\left(\beta \theta_{w}\right)^{k} \frac{D_{c, t+k} N_{t+k \mid t}}{\left(C_{t+k}-b C_{t+k-1}\right)}\left\{\frac{W_{t}^{*}}{P_{t+k}}-\frac{\varepsilon_{w}}{\varepsilon_{w}-1} D_{n, t+k} N_{t+k \mid t}^{\eta}\left(C_{t+k}-b C_{t+k-1}\right)\right\}=0$

where $N_{t+k \mid t}=\left(\frac{W_{t}^{*}}{W_{t+k}}\right)^{-\varepsilon_{w}} N_{t+k}$.

The evolution of the aggregate wage index is given by

$$
W_{t}=\left[\theta_{w} W_{t-1}^{1-\varepsilon_{w}}+\left(1-\theta_{w}\right)\left(W_{t}^{*}\right)^{1-\varepsilon_{w}}\right]^{\frac{1}{1-\varepsilon_{w}}} .
$$

\section{A.2 Firms}

The model has final goods, differentiated intermediate goods and composite intermediate goods producers. Final goods producers purchase a composite of intermediate home goods, $Y_{H, t}$, and a composite of intermediate foreignproduced goods, $Y_{F, t}$, to produce a homogeneous final good product that is non-tradable across countries. Intermediate differentiated domestic and foreign goods producers operate under sticky prices and monopolistic competition, and sell their products to intermediate domestic and foreign composite goods producers, who in turn sell these to final goods producers. Composite intermediate goods are traded across countries.

\section{A.2.1 Final good producers and "Iceberg" costs}

A continuum of final goods producers firms purchase a composite of intermediate home goods, $Y_{H, t}$, and a composite of intermediate foreign-produced goods, $Y_{F, t}$, to produce a homogeneous final good product. A fraction $\tau$ of imported intermediate inputs are lost in transit between the two countries. This functional form for transportation costs was first proposed by Samuelson (1954), and is also known in the literature as "iceberg costs". Therefore, the production of the final good is given by:

$$
Y_{t}=\left\{\omega^{\frac{1}{\theta}} Y_{H, t}^{\frac{\theta-1}{\theta}}+(1-\omega)^{\frac{1}{\theta}}\left[(1-\tau) Y_{F, t}\right]^{\frac{\theta-1}{\theta}}\right\}^{\frac{\theta}{\theta-1}},
$$

where $\omega$ denotes the fraction of home-produced goods that are used for the production of the final good, and $\theta$ denotes the elasticity of substitution between domestically produced and imported intermediate goods in both 
countries. The prices of these composite goods for the final good producers are given by $P_{H, t}$ and $P_{F, t}$.

The demand function for both types of goods is given by:

$$
Y_{H, t}=\omega\left(\frac{P_{H, t}}{P_{t}}\right)^{-\theta} Y_{t}, \quad Y_{F, t}=(1-\omega)(1-\tau)^{(\theta-1)}\left(\frac{P_{F, t}}{P_{t}}\right)^{-\theta} Y_{t}
$$

and the price level is given by:

$$
P_{t}=\left[\omega\left(P_{H, t}\right)^{1-\theta}+(1-\omega)\left(\bar{P}_{F, t}\right)^{1-\theta}\right]^{\frac{1}{1-\theta}}
$$

where we have defined $\bar{P}_{F, t}=P_{F, t} /(1-\tau)$. That is, what matters for the definition of the price level is the after-iceberg cost price of imported goods. Finally, we can rewrite the weights as follows in the production function of the final good:

$$
Y_{t}=\left[\omega^{\frac{1}{\theta}} Y_{H, t}^{\frac{\theta-1}{\theta}}+\left(1-\omega^{*}\right)^{\frac{1}{\theta}}\left(Y_{F, t}\right)^{\frac{\theta-1}{\theta}}\right]^{\frac{\theta}{\theta-1}}
$$

where

$$
\left(1-\omega^{*}\right)=(1-\omega)(1-\tau)^{\theta-1} .
$$

A higher rate of transportation costs $\tau$, or an increase in the elasticity of substitution $\theta$ decreases the value of $\left(1-\omega^{*}\right)$, and raises the home bias in the economy. In the Bayesian estimation of the model we fix the parameter $\omega$ and then estimate $\tau$ and $\theta$.

\section{A.2.2 Intermediate domestic composite goods producers}

Intermediate domestic composite good producers buy differentiated intermediate goods from domestic producers and aggregate them into the composite domestic good. The composite intermediate domestic goods are:

$$
Y_{H, t}=\left[\left(\frac{1}{n}\right)^{\varepsilon_{p}} \int_{0}^{n} Y_{H, t}(h)^{\frac{\varepsilon_{p}-1}{\varepsilon_{p}}} d h\right]^{\frac{\varepsilon_{p}}{\varepsilon_{p}-1}}
$$

where $\varepsilon_{p}>1$ denotes is the elasticity of substitution between types of intermediate goods. The demand for each type of good is given by: 


$$
Y_{H, t}(h)=\left[\frac{P_{H, t}(h)}{P_{H, t}}\right]^{-\varepsilon_{p}} Y_{H, t}, \text { for all } h \in[0,1]
$$

and

$$
P_{H, t}^{1-\varepsilon_{p}}=\frac{1}{n} \int_{0}^{n} P_{H, t}^{1-\varepsilon_{p}}(h) d h
$$

\section{A.2.3 Intermediate foreign composite goods producers}

Intermediate foreign composite good producers export differentiated intermediate goods from the foreign country by aggregating them into the composite foreign good. The production function for composite final foreign goods is given by

$$
Y_{F, t}=\left[\left(\frac{1}{1-n}\right)^{\varepsilon_{p}} \int_{n}^{1} Y_{F, t}(f)^{\frac{\varepsilon_{p}-1}{\varepsilon_{p}}} d f\right]^{\frac{\varepsilon_{p}}{\varepsilon_{p}-1}},
$$

where $\varepsilon_{p}>1$ denotes is the elasticity of substitution between types of intermediate goods. The demand for each type of good is given by:

$$
Y_{F, t}(f)=\left[\frac{P_{F, t}(f)}{P_{F, t}}\right]^{-\varepsilon_{p}} Y_{F, t}, \text { for all } f \in[0,1],
$$

and

$$
P_{F, t}^{1-\varepsilon_{p}}=\frac{1}{1-n} \int_{n}^{1} P_{F, t}^{1-\varepsilon_{p}}(f) d f .
$$

Once the intermediate composite goods are produced, a fraction is sold to the domestic market and rest is sold to the other country through the firms in the transportation sector. Our baseline is a model with local currency pricing, meaning that prices are sticky in the currency of the destination market and the law of one price (without iceberg costs) does not hold outside the steady state.

\section{A.2.4 Intermediate Differentiated Goods Producers}

In each country, there is a continuum of intermediate goods producers, each producing a type of good that is an imperfect substitute of the others, using domestic capital and labor. These differentiated intermediate goods are sold to the composite differentiated goods producers. 
Technology The production function of each intermediate good in the home country is given by

$$
Y_{H, t}(h)+Y_{H, t}^{*}(h)=\left[A_{t} N_{t}(h) X_{t}\right]^{1-\alpha}\left[K_{t-1}(h)\right]^{\alpha},
$$

where $\alpha$ is the share of capital in the production function. The above production function has two technology shocks. The first one, $X_{t}$, is a world technology shock, that affects the two countries the same way: it has a unit root, as in Galí and Rabanal (2005), Lubik and Schorfheide (2006), and Rabanal and Tuesta (2010). In addition, there is a labor-augmenting country specific technology shock, $A_{t}$, that evolves as an $A R(1)$ process. The evolution of technology shocks is as follows

$$
\begin{aligned}
\log \left(X_{t}\right) & =\log \left(X_{t-1}\right)+\varepsilon_{t}^{x}, \\
\log \left(A_{t}\right) & =\rho_{a} \log \left(A_{t-1}\right)+\varepsilon_{t}^{a} .
\end{aligned}
$$

From cost minimization the real marginal cost of production is given by

$$
M C_{t}(h)=\frac{\left(\frac{W_{t} / P_{t}}{A_{t}}\right)^{1-\alpha}\left(R_{t}^{K}\right)^{\alpha}}{X_{t}^{1-\alpha} \alpha^{\alpha}(1-\alpha)^{(1-\alpha)}}=M C_{t} .
$$

Note that the marginal cost is not firm-specific but rather depends on aggregate variables: all firms receive the same technology shock and all firms rent inputs at the same price. The optimal capital-output ratio is also not firm-specific and given by:

$$
\frac{N_{t}(h)}{K_{t-1}(h)}=\frac{N_{t}}{K_{t-1}}=\frac{(1-\alpha)}{\alpha}\left(\frac{R_{t}^{K}}{W_{t} / P_{t}}\right) .
$$

Nominal Price Rigidities and Local Currency Pricing Once they have solved for the optimal capital-output ratio and cost minimization, intermediate good producers choose the price that maximizes discounted profits subject to a Calvo-type restriction. In our baseline model, we assume local currency pricing (LCP) for goods that are shipped internationally: a firm chooses a price for the domestic market and a price for the foreign market, each price quoted in the destination market currency. Hence, there is price stickiness in each country's imports prices in terms of local currency.

In each period, a fraction $1-\theta_{H}$ of firms that set prices in the domestic market change their prices. Additionally, we assume that the prices of each 
firm that cannot reoptimize in a given period is adjusted according to the indexation rules:

$$
\frac{P_{H, t}(h)}{P_{H, t-1}(h)}=\left(\Pi_{H, t-1}\right)^{\lambda_{H}}, \text { and } \frac{P_{H, t}^{*}(h)}{P_{H, t-1}^{*}(h)}=\left(\Pi_{H, t-1}^{*}\right)^{\lambda_{H}}
$$

where $0<\lambda_{H}<1$. Therefore, conditioned on a having set an optimal price from period $t$, the present discounted value of firm $h$ profits is:

$\underset{P_{H, t}(h), P_{H, t}^{*}(h)}{\operatorname{Max}} E_{t}\left\{\begin{array}{l}\sum_{k=0}^{\infty}\left(\beta \theta_{H}\right)^{k} \Lambda_{t, t+k}\left[\frac{P_{H, t}(h)}{P_{t+k}}\left(\frac{P_{H, t+k-1}}{P_{H, t-1}}\right)^{\lambda_{H}}-M C_{t+k}\right] Y_{H, t+k \mid t}(h)+ \\ \sum_{k=0}^{\infty}\left(\beta \theta_{H}\right)^{k} \Lambda_{t, t+k}\left[\frac{S_{t} P_{H, t}^{*}(h)}{P_{t+k}}\left(\frac{P_{H, t+k-1}^{*}}{P_{H, t-1}^{*}}\right)^{\lambda_{H}}-M C_{t+k}\right] Y_{H, t+k \mid t}^{*}(h)\end{array}\right\}$,

where $P_{H, t}(h)$ and $P_{H, t}^{*}(h)$ are prices of $\operatorname{good} h$ in the home and foreign markets, and whose evolution depends on the indexation rules, and $Y_{H, t+k \mid t}(h)$ and $Y_{H, t+k \mid t}^{*}(h)$ are the associated demands for intermediate good $h$ in each country.

The first order conditions to the home intermediate goods producers firms for the home and foreign market are:

$$
\begin{aligned}
& \frac{\hat{P}_{H, t}(h)}{P_{H, t}}=\frac{\varepsilon_{p}}{\varepsilon_{p}-1} \frac{E_{t} \sum_{k=0}^{\infty}\left(\beta \theta_{H}\right)^{k} \Lambda_{t, t+k} M C_{t+k} Y_{H, t+k}\left[\frac{P_{H, t}}{P_{H, t+k}}\left(\frac{P_{H, t+k-1}}{P_{H, t-1}}\right)^{\infty}\left(\beta \theta_{H}\right)^{k} \Lambda_{t, t+k} Y_{H, t+k}\left(\frac{P_{H, t}}{P_{H, t+k}} \frac{P_{H, t+k}}{P_{t+k}}\right)^{-\varepsilon_{p}}\left(\frac{P_{H, t+k-1}}{P_{H, t-1}}\right)^{\lambda_{H}\left(1-\varepsilon_{p}\right)}\right.}{}, \\
& \frac{\hat{P}_{H, t}^{*}(h)}{P_{H, t}^{*}}=\frac{\varepsilon_{p}}{\varepsilon_{p}-1} \frac{E_{t} \sum_{k=0}^{\infty}\left(\beta \theta_{H}\right)^{k} \Lambda_{t, t+k} \frac{M C_{t+k}}{R E R_{t+k}} Y_{H, t+k}^{*}\left[\frac{P_{H, t}^{*}}{P_{H, t+k}^{*}}\left(\frac{P_{H, t+k-1}^{*}}{P_{H, t-1}^{*}}\right)^{\lambda_{H}^{*}}\right]^{-\varepsilon_{p}}}{\left(\beta \theta_{H}\right)^{k} \Lambda_{t, t+k} Y_{H, t+k}^{*}\left(\frac{P_{H, t}^{*}}{P_{H, t+k}^{*}} \frac{P_{H, t+k}^{*}}{P_{t+k}^{*}}\right)^{1-\varepsilon_{p}}\left(\frac{P_{H, t+k-1}^{*}}{P_{H, t-1}^{*}}\right)^{\lambda_{H}^{*}\left(1-\varepsilon_{p}\right)}} .
\end{aligned}
$$

Equation (37) is the usual optimal price condition under a Calvo-type restriction with indexation, and includes the demand coming from both domestic and foreign firms. Equation (38) is the expression for the price of exports and transforms the relevant real marginal cost of production to foreign currency by using the real exchange rate. Note that the coefficients reflecting the degree of nominal rigidity are the same for domestic inflation and for exports. 
The evolution of the home-produced intermediate goods price indices in the home and foreign countries are, given indexation:

$$
\begin{aligned}
& P_{H, t}^{1-\varepsilon_{p}}=\left(1-\theta_{H}\right)\left(\hat{P}_{H, t}\right)^{1-\varepsilon_{p}}+\theta_{H}\left[P_{H, t-1}\left(\frac{P_{H, t-1}}{P_{H, t-2}}\right)^{\lambda_{H}}\right]^{1-\varepsilon_{p}}, \\
& P_{H, t}^{* 1-\varepsilon_{p}}=\left(1-\theta_{H}\right)\left(\hat{P}_{H, t}^{*}\right)^{1-\varepsilon_{p}}+\theta_{H}\left[P_{H, t-1}^{*}\left(\frac{P_{H, t-1}^{*}}{P_{H, t-2}^{*}}\right)^{\lambda_{H}}\right]^{1-\varepsilon_{p}} .
\end{aligned}
$$

\section{A.3 Closing the Model}

In order to close the model, we impose market-clearing conditions for all types of home and foreign intermediate goods. For all aggregate intermediate goods, we need to take into account the size of the countries and transportation costs. Hence, we multiply per capita quantities by the size of each sector.

$$
n G D P_{t}=n\left(A_{t} N_{t} X_{t}\right)^{1-\alpha} K_{t-1}^{\alpha}=n Y_{H, t}+(1-n) \tau Y_{H, t}^{*}+(1-n)(1-\tau) Y_{H, t}^{*}
$$

Notice that a fraction $\tau$ of the exports is assigned to transportation costs and the rest is demanded by the foreign country. For the final good, the market clearing condition in the home country is:

$$
Y_{t}=C_{t}+I_{t}+G_{t}
$$

We introduce an exogenous demand shock for each country $\left(G_{t}, G_{t}^{*}\right)$ which can be interpreted as government expenditure shocks that evolve as $A R(1)$ processes in logs. We assume that both governments run a balanced budget every period (i.e. $G_{t}=T_{t}$ and $G_{t}^{*}=T_{t}^{*}$ ).

The law of motion of the internationally traded bonds is written in aggregate terms and is given by :

$$
\frac{n S_{t} D_{t}}{P_{t} R_{t}^{*} \Psi\left(\frac{S_{t} D_{t}}{P_{t} Y_{t}}\right) U_{t}}=\frac{n S_{t} D_{t-1}+N X_{t}}{P_{t}}
$$


where real net exports $\left(\frac{N X_{t}}{P_{t}}\right)$ are given by

$$
\frac{N X_{t}}{P_{t}}=\frac{(1-n) S_{t} P_{H, t}^{*} Y_{H, t}^{*}-n P_{F, t} Y_{F, t}}{P_{t}} .
$$

Finally, we assume that both countries follow a monetary policy rule that targets deviations of domestic CPI inflation and real GDP growth from their steady-state values, that we normalize to zero:

$$
\frac{R_{t}}{R}=\left(\frac{R_{t-1}}{R}\right)^{\varphi_{R}}\left[\left(P_{t} / P_{t-1}\right)^{\varphi_{\pi}}\left(G D P_{t} / G D P_{t-1}\right)^{\varphi_{y}}\right]^{1-\varphi_{R}} \exp \left(\varepsilon_{t}^{m}\right) .
$$

\section{References}

[1] Adolfson, M., S. Laséen, J. Lindé, and M. Villani, 2007, "Bayesian Estimation of an Open Economy DSGE model with Incomplete PassThrough," Journal of International Economics, 72, 481-511.

[2] An, Sungbae, and Frank Schorfheide, 2007, "Bayesian analysis of DSGE models, " Econometric Reviews, 26, pp. 211-219.

[3] Anderson, James E. and Eric van Wincoop, 2004, "Trade Costs," Journal of Economic Literature, 42(2): 691-751.

[4] Benigno, Paolo, 2009, "Price stability with imperfect financial integration," Journal of Money, Credit, and Banking, 41, pp. 121-149.

[5] Christiano, L. J., M. Eichenbaum, and C. L. Evans, 2005, "Nominal Rigidities and the Dynamic Effects of a Shock to Monetary Policy," Journal of Political Economy, 113, 1-45.

[6] DiCecio, Riccardo and Edward Nelson, 2007, "An Estimated DSGE Model for the United Kingdom," Federal Reserve Bank of St. Louis Review, July/August 2007, 89(4), pp. 215-231.

[7] Erceg, Cristopher, David Henderson, and Andrew Levin, 2001, "Optimal monetary policy with staggered wage and price contracts," Journal of Monetary Economics, 46, pp. 281-313. 
[8] Erceg, Cristopher, and Jesper Lindé, 2010, "Asymmetric Shocks in a Currency Union with Monetary and Fiscal Handcuffs," International Finance Discussion Papers No. 1012.

[9] Feenstra, Robert C., 1996, "NBER Trade Database, Disk 1: U.S. Imports, 1972-1994: Data and Concordances," NBER Working Paper No. 5515 .

[10] Feldstein, Martin, 2010, "Let Greece Take a Eurozone Holiday," Financial Times (February 16).

[11] Fernández-Villaverde, Jesús, Pablo Guerron-Quintana, Juan F. RubioRamirez, and Martín Uribe, 2011. "Risk Matters: The Real Effects of Volatility Shocks," American Economic Review, 101(6), pp.2530-2561.

[12] Galí, Jordi, and Pau Rabanal, 2005, "Technology shocks and aggregate fluctuations: How well does the RBC model fit postwar U.S. data," M. Gertler, K. Rogoff (Eds.), NBER Macroeconomics Annual, vol. 19, The MIT Press, Cambridge, pp. 225-288.

[13] García-Cicco, Javier, Roberto Pancrazi, and Martín Uribe, 2010, "Real Busines Cycles in Emerging Countries?," American Economic Review, 100(5), pp. 2510-2531.

[14] HM Treasury, 1997, "UK Membership of the Single Currency: An Assessment of the Five Economic Tests," Available at: http://www.hmtreasury.gov.uk/d/single.pdf.

[15] HM Treasury, 2003, "UK Membership of the Single Currency: An Assessment of the Five Economic Tests," Available at: http://webarchive.nationalarchives.gov.uk/+/http://www.hmtreasury.gov.uk/euro_assess03_repindex.htm

[16] Hummels, David, 2001, "Toward a Geography of Trade Costs," Working Paper, Purdue University.

[17] Justiniano, Alejandro, Giorgio E. Primiceri, and Andrea Tamablotti, 2010, "Investment Shocks and Business Cycles," Journal of Monetary Economics, 57(2), pp. 132-145. 
[18] Kose, M. Ayhan, and Kei-Mu Yi, 2006, "Can the standard international business cycle model explain the relation between trade and comovement?," Journal of International Economics, 68(2), pp. 267-295.

[19] Lubik, Thomas, and Frank Schorfheide, 2006, "A Bayesian look at new open economy macroeconomics," M. Gertler, K. Rogoff (Eds.), NBER Macroeconomics Annual, vol. 20, The MIT Press, Cambridge, pp. 313380 .

[20] Lucas, Robert E., Jr., 1987, "Models of Business Cycles" New York: Basil Blackwell.

[21] Mundell, Robert A., 1961, "A Theory of Optimum Currency Areas," American Economic Review, 51(4), pp. 657-665.

[22] Obstfeld, Maurice, and Kenneth Rogoff, 2000, "The Six Major Puzzles in International Macroeconomics: Is There a Common Cause?," B. Bernanke and K. Rogoff, (Eds.), NBER Macroeconomics Annual, vol. 15, The MIT Press, Cambridge, pp. 339-412.

[23] Primiceri, Giorgio E., Ernst Schaumburg, and Andrea Tambalotti, 2006. "Intertemporal disturbances," NBER Working Paper No. 12243.

[24] Rabanal, Pau and Vicente, Tuesta, 2010, "Euro-dollar real exchange rate dynamics in an estimated two-country model: An assessment," Journal of Economic Dynamics and Control, 34 (4): 780-797.

[25] Rabanal, Pau, 2009, "Inflation Differentials between Spain and the EMU: A DSGE Perspective," Journal of Money, Credit and Banking, 41: 1141-1166.

[26] Ravn, Morten O., and Elisabetta Mazzenga, 2004, "International business cycles: the quantitative role of transportation costs," Journal of International Money and Finance, 23(4): 645-671.

[27] Rose, Andrew, 2008, "EMU, Trade and Business Cycle Synchronization," Mimeo, Haas School of Business, University of California, Berkeley.

[28] Roubini, Nouriel, 2011, "Greece Should Default and Abandon the Euro," Financial Times (September 19). 
[29] Samuelson, P.A., 1954, "The Transfer Problem and the Transport Costs, II:Analysis of Effects of Trade Impediments," Economic Journal, 645, 264-289.

[30] Santos Silva, João M.C., and Silvana Tenreyro, 2010, "Currency Unions in Prospect and Retrospect," Annual Review of Economics, 2, 51-74.

[31] Schmitt-Grohé, S. and M. Uribe, 2003, "Closing Small Open Economy Models," Journal of International Economics, 61, 163-185.

[32] Schmitt-Grohé, S. and M. Uribe, 2007, "Optimal Simple and Implementable Monetary and Fiscal Rules," Journal of Monetary Economics, 54, 1702-1725.

[33] Shimer, Robert, 2010, "Wage Rigidites and Jobless Recoveries," Working Paper, University of Chicago.

[34] Smets, Frank, and Rafael Wouters, 2007, "Shocks and Frictions in US Business Cycles: A Bayesian DSGE Approach." American Economic Review, 97 (3): 586-606. 
Monetary Policy Rates in United Kingdom and the Euro Area 1999 -2011

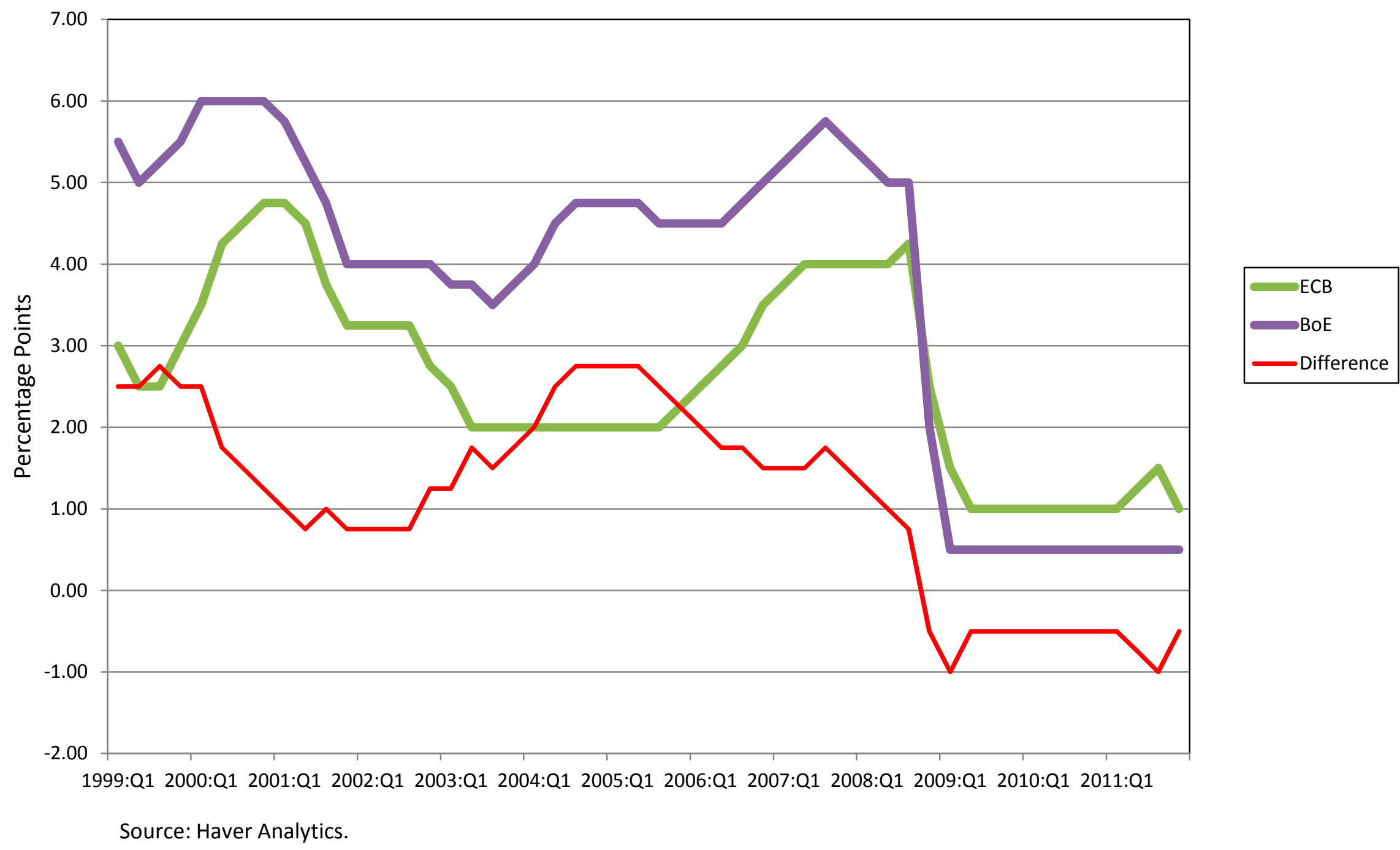

(C)International Monetary Fund. Not for Redistribution 
Figure 2

Trade with Euro Area in France, Germany, Italy, Spain and the United Kingdom $1990-2010$

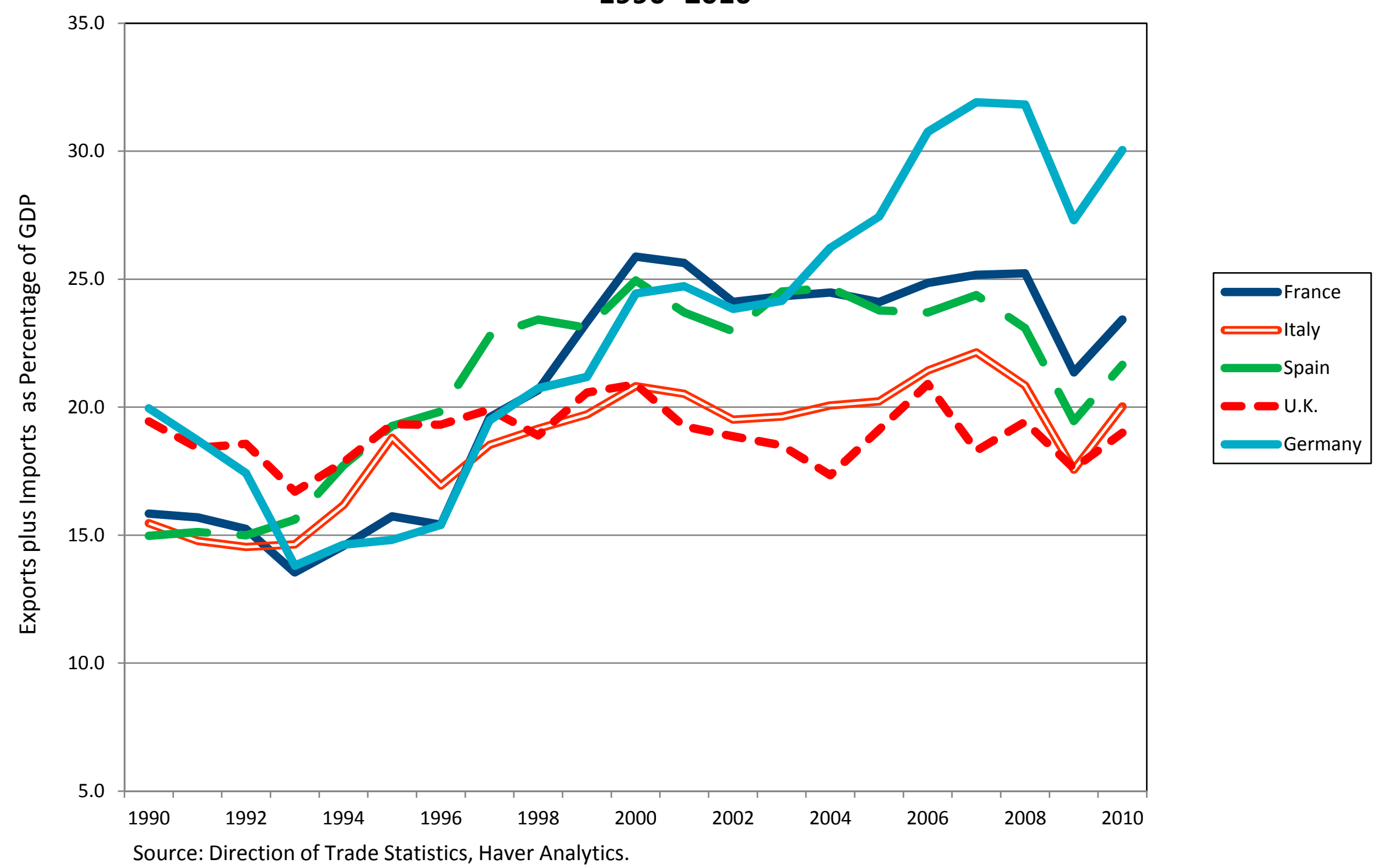

(C)International Monetary Fund. Not for Redistribution 


\section{Figure 3}

Risk Premium in France, Italy, Spain and the United Kingdom 1990 -2011

8

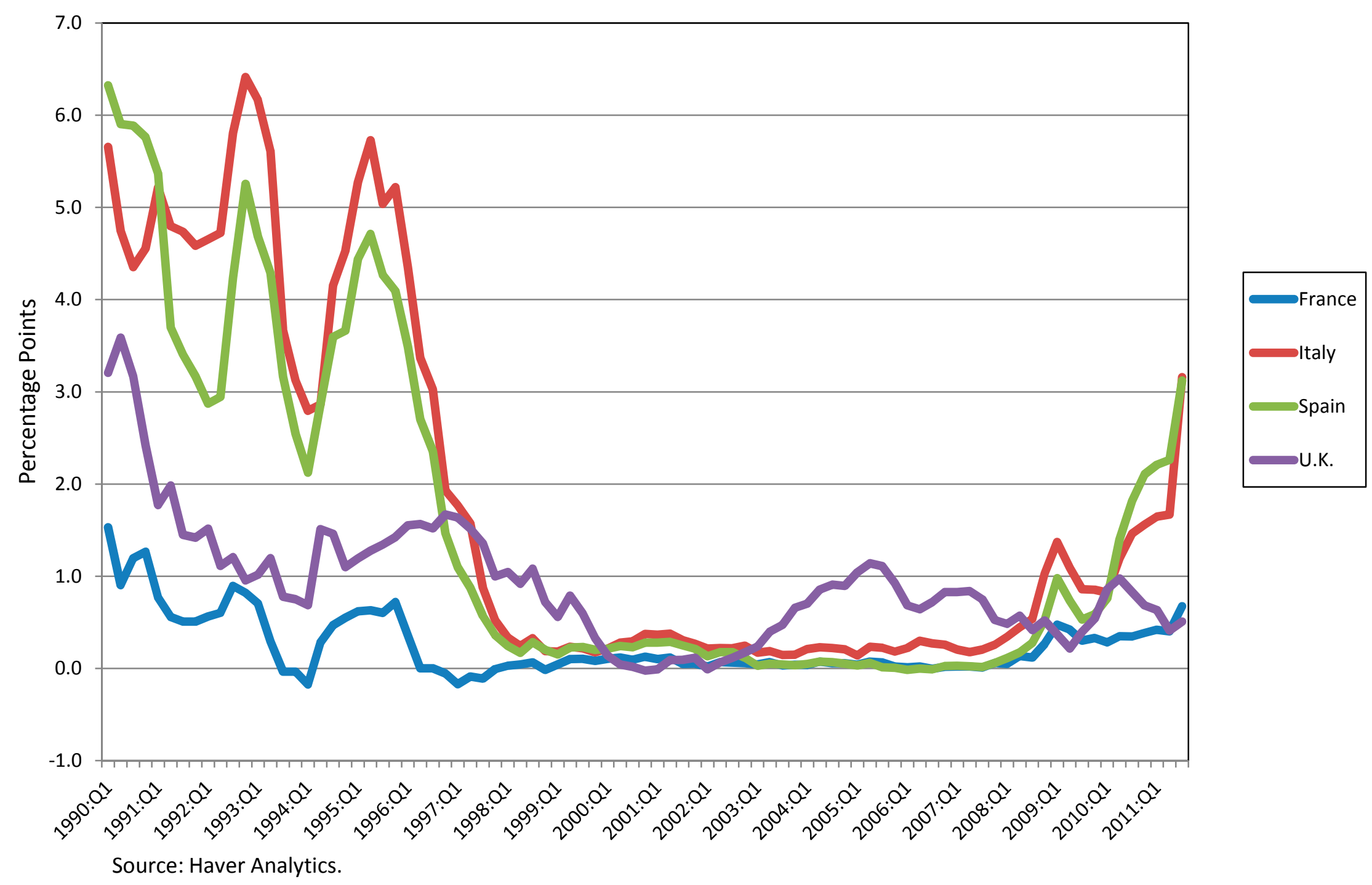

CInternational Monetary Fund. Not for Redistribution 

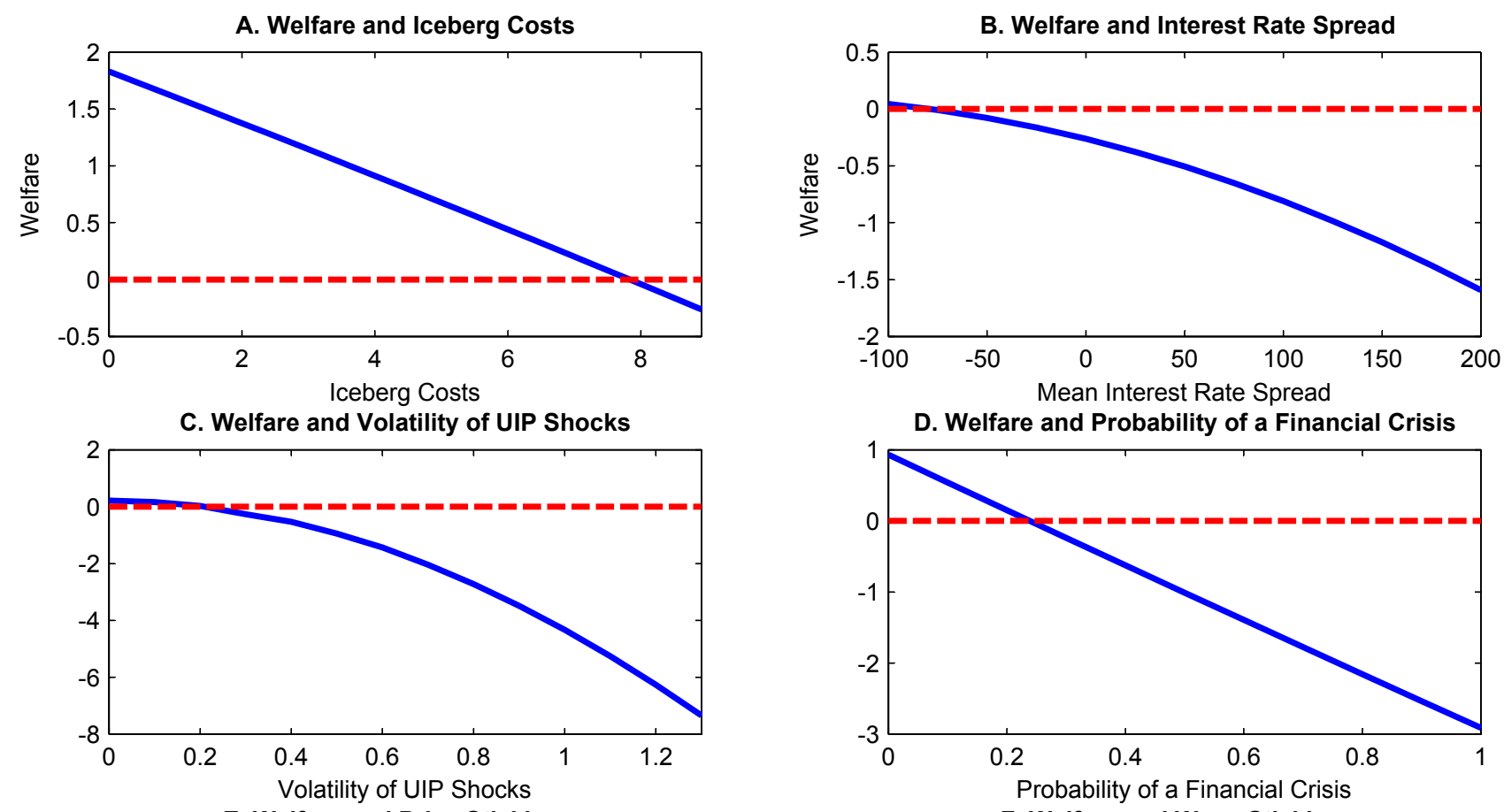

D. Welfare and Probability of a Financial Crisis


F. Welfare and Wage Stickiness

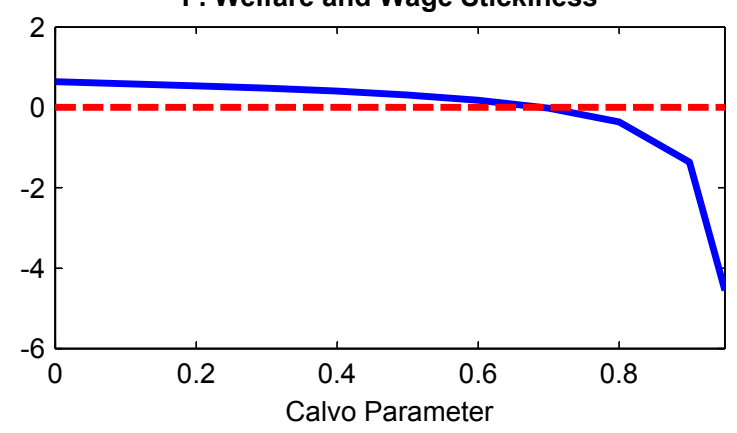

Welfare

Figure 5: Sensitivity Analysis of Welfare. 